\title{
Anurans of the Parque Municipal de Piraputangas, on the western border of the Pantanal, Mato Grosso do Sul, Brazil
}

\author{
Alessandher Piva ${ }^{1}$, Fernanda Martins dos Santos ${ }^{1}$, Arianna da Silva Costa-Urquiza ${ }^{1}$, \\ Michelly Pereira Soares ${ }^{1}$, Marcus Vinícius Santiago Urquiza ${ }^{1}$, Nelson Rufino de Albuquerque ${ }^{2,3}$ \\ 1 Laboratório de Zoologia, Campus do Pantanal, Universidade Federal de Mato Grosso do Sul, Avenida Rio Branco 1270, 79304-902 Corumbá, MS, \\ Brazil. 2 Laboratório de Zoologia, Instituto de Biociências, Universidade Federal de Mato Grosso do Sul, Avenida Costa e Silva s/n, 79070-900 \\ Campo Grande, MS, Brazil. 3 Programa de Pós-Graduação em Biologia Animal, Universidade Federal de Mato Grosso do Sul. \\ Corresponding author: Nelson Rufino de Albuquerque, nelson_rufino@hotmail.com
}

\begin{abstract}
We present an annotated list of anuran species found in the Parque Municipal de Piraputangas, a protected area of a semi-deciduous forest located in Corumbá, Mato Grosso do Sul, Brazil. Fieldwork was conducted three times per month between August 2012 and July 2013. We recorded 29 species from six families (Bufonidae, Dendrobatidae, Hylidae, Leptodactylidae, Microhylidae, and Phyllomedusidae), representing $30 \%$ of the anuran species known to occur in Mato Grosso do Sul and 50\% of the anurans recorded in this state's semi-deciduous forests. Microhylids, leptodactylids, and bufonids were associated with terrestrial substrates, whereas most hylids and phyllomedusids were found perched on vegetation. This study will fill gaps in the knowledge on the anuran fauna of the western border of the Pantanal and will serve as a basis for additional studies that are needed to understand how species respond to habitat loss or fragmentation, such as landscape conversions, commercial logging, or mining.
\end{abstract}

Keywords

Amphibians, Central-Western Brazil, natural history, protected area, taxonomy

Academic editor: Manuella Folly | Received 4 September 2020 | Accepted 28 November 2020 | Published 21 December 2020

Citation: Piva A, dos Santos FM, da Silva Costa-Urquiza A, Soares MP, Urquiza MVS, de Albuquerque NR (2020) Anurans of the Parque Municipal de Piraputangas, on the western border of the Pantanal, Mato Grosso do Sul, Brazil. Check List 16 (6): 1709-1724. https://doi.org/10.15560/16.6.1709

\section{Introduction}

In central-western Brazil, the state of Mato Grosso do Sul is home to 98 species of amphibians, or approximately 9\% of the Brazilian amphibian fauna (Segalla et al. 2019). Fifty-six anuran species are known to occur in floodplain areas, which are mostly represented by the Pantanal (the world's largest tropical wetlands), and 92 species in the surrounding Cerrado (Piva et al. 2017; Souza et al. 2017). Recently, Souza et al. (2017) compiled and verified the amphibian species present in Mato Grosso do Sul for the first time. They conducted an extensive literature review of species known to occur in the state and highlighted areas, such as the Serra de Maracaju, the Brazilian Chaco, the Taquari-Itiquira plateaus, and the inland areas of the Pantanal, where future surveys could be focused to ensure representative coverage of the whole state.

The paucity of anuran faunal records is particularly striking in the northern and southern regions of Mato Grosso do Sul (Souza et al. 2017). Compared to other regions, the anuran fauna of Corumbá, the westernmost city in Mato Grosso do Sul, has been more thoroughly surveyed (e.g., Ávila and Ferreira 2004; Piva 2014), but the composition and patterns of abundance of the 
herpetofauna of several regions of the Pantanal remain virtually unknown (Strüssmann et al. 2011). This is partly owing to the difficulty in accessing the floodplain when the road access and some areas are inundated during flood season (e.g., Penha et al. 2010; Boff et al. 2013). The western border of the Pantanal is characterized by the residual Urucum-Amolar plateaus, which lie at $800-$ 1,065 $\mathrm{m}$ a.s.1., and other elevated landforms (Ab'Saber 1988). The Pantanal also has a variety of types of plant formations, such as the Cerrado savanna (stricto sensu), seasonal semi-deciduous forests, deciduous forests, gallery forests, and cangas (Pott et al. 2000; Lehn et al. 2008; Takahasi and Meireles 2010). Seasonal semi-deciduous and deciduous forests, in particular, occur infrequently in floodplain areas and are mostly distributed between the Bodoquena plateau and the residual Urucum-Amolar plateau (Damasceno-Junior et al. 2009).

Seasonal semi-deciduous and deciduous forests harbor high biodiversity; however, their natural habitats are threatened by anthropogenic activities, such as conversion to pasture, commercial logging, and mining (Miles et al. 2006; Roque et al. 2016). This reinforces the importance of continuing fieldwork to investigate the fauna of the western border of the Pantanal (Tomas et al. 2019). Moreover, amphibians are the focus of recent debate and public attention owing to the global decline in their populations. In addition, they are one of the most threatened ( $41 \%$ of species threatened; IUCN 2020$)$ and poorly known groups of vertebrates in several geographic areas (Amaral et al. 2019). Therefore, studies on anuran biology are important in formulating adequate strategies for the conservation of anurans (Silvano and Segalla 2005). Along the western border of the Pantanal, previous studies have included an investigation into the breeding biology of Lysapsus limellum Cope, 1862a (Prado and Uetanabaro 2000), a survey of frog diversity in the surrounding plateaus of the southern Pantanal (Gordo and Campos 2005), and studies on the calling behavior, breeding biology, reproductive modes, and habitat use of frogs (Ávila and Ferreira 2004; Prado et al. 2005). Studies have also included the efficiency of sampling frogs using the RAPELD method in two areas of the Pantanal which are subject to periodic flooding (Valério-Brun et al. 2010), anuran species richness and abundance in the northwestern Pantanal (Pansonato et al. 2011), and the recording of nine species in the Parque Municipal de Piraputangas, a protected area approximately $25 \mathrm{~km}$ south of Corumbá (Prefeitura Municipal de Corumbá 2008). Here, we estimate the diversity and provide a description and provide notes on sex, size, and natural history of each anuran species in the Parque Municipal de Piraputangas, Corumbá. This list aims to fill gaps in the knowledge of the anuran fauna on the western border of the Pantanal.

\section{Study Area}

The list of species is based on collections made in three randomly chosen sites of the Parque Municipal de Piraputangas (PMP) (at its approximate center: $19^{\circ} 16^{\prime} \mathrm{S}$, $057^{\circ} 38^{\prime} \mathrm{W}$; datum: WGS 84; Fig. 1) between August

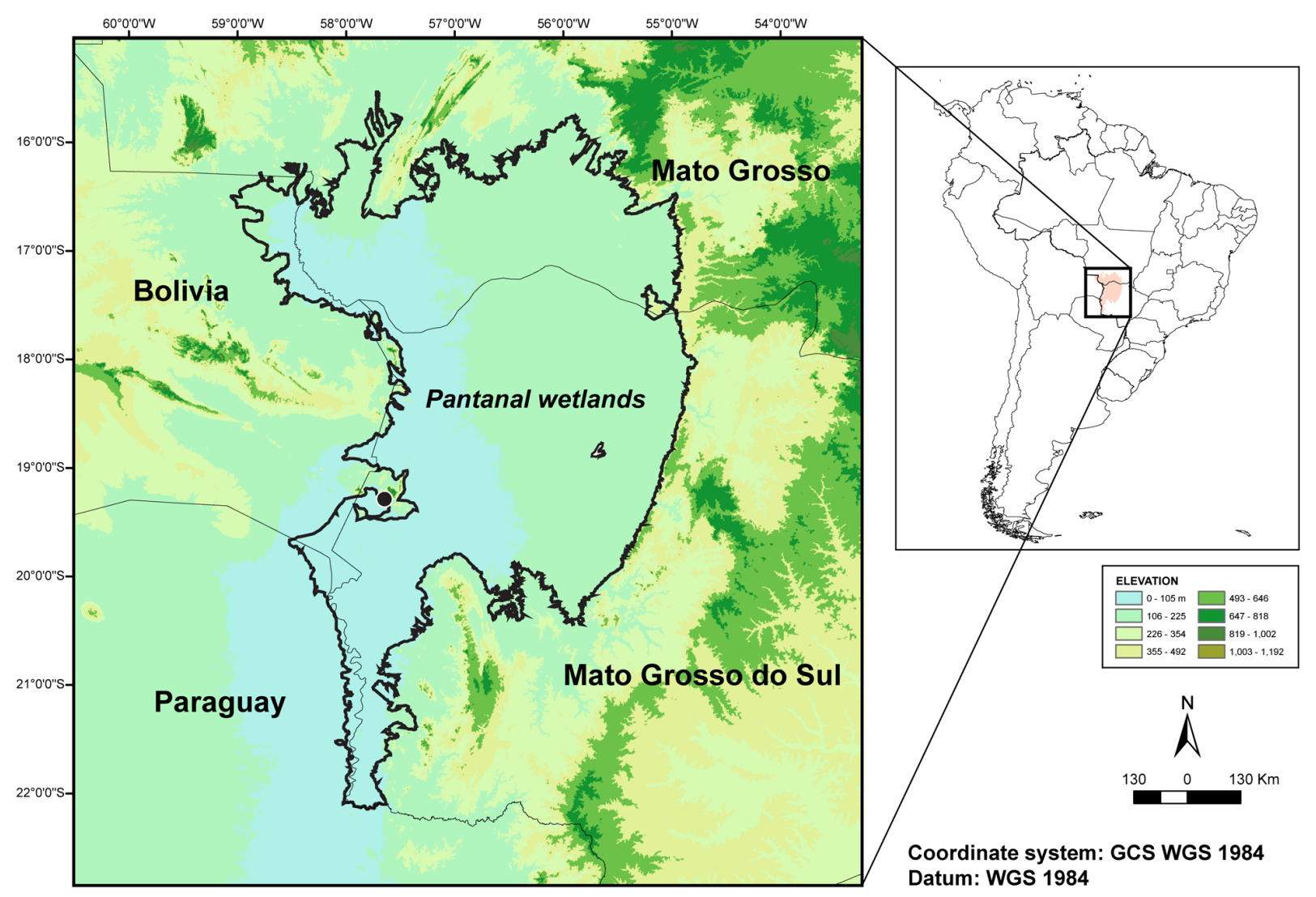

Figure 1. Location of Parque Municipal de Piraputangas in Corumbá, Mato Grosso do Sul. 
2012 and July 2013. Boana punctata (Schneider, 1799) and Ameerega picta (Tschudi, 1838) were recorded after the completion of our field surveys. PMP is a protected area of 1300 ha located approximately $25 \mathrm{~km}$ south of the urban area of Corumbá, Mato Grosso do Sul, Brazil (Prefeitura Municipal de Corumbá 2008). Corumbá is the largest municipality in the state, comprising $18 \%$ of the state's territory. As much as $95.6 \%$ of Corumbá is within the Pantanal ecosystem (Silva and Abdon 1998). According to the Köppen and Geiger climate classification (Peel et al. 2007), Corumbá has a tropical dry climate (savannah climate), with the average monthly temperature greater than $18{ }^{\circ} \mathrm{C}$ throughout the year; approximately $1074 \mathrm{~mm}$ of rain falls annually. The predominant, or original, vegetation of the park is semi-deciduous forest; however, large areas have been cleared or heavily modified for pasture, logging, and mining (Prefeitura Municipal de Corumbá 2008).

We informally named our sites (Fig. 2) as: Area 1, $120 \mathrm{~m}$ a.s.l., which is characterized by seasonal forest, with a stone-bottomed stream, and leaf litter accumulation on the margins of the São Domingos stream; Area 2, $120 \mathrm{~m}$ a.s.l, which is a disturbed area characterized by rocky soils and herbaceous strata comprising grasses and two permanent and several ephemeral ponds; and Area 3 (behind the entrance of PMP), $180 \mathrm{~m}$ a.s.l, with phytophysiognomy similar to that of Area 1, but with reduced accumulation of leaf litter along the margins of Piraputangas stream. Area 3 is affected by the regular flow of mining vehicles in front of the entrance of the PMP.

\section{Methods}

During each individual encounter, we recorded the substrate on which the anuran was first seen: aquatic (in temporary ponds, permanent ponds, and streams), arboreal (perched on vegetation), grassy (on the herbaceous ground, dominated by grasses, and usually in the surroundings of permanent ponds), rocky (at the edge of stone-bottomed streams), leaf litter (on dead plant material such as leaves, barks, twigs, or fallen trunks), and soil (on bare soils, devoid of dense plant cover or on cleared trails).

We surveyed the PMP three times a month at night, from 18:00 to 22:00 h. During each survey, five researchers slowly walked along streams and ponds while looking for adult anurans. The resulting sampling effort was $144 \mathrm{~h}$ per person. We detected 756 anurans using the visual encounter method (Crump and Scott 1994). These detections were supplemented by 33 voucher specimens, which we captured and preserved according to the techniques outlined by McDiarmid (1994). We determined the height of the perch using a tape measure, starting the measurement from the ground surface. We did not record
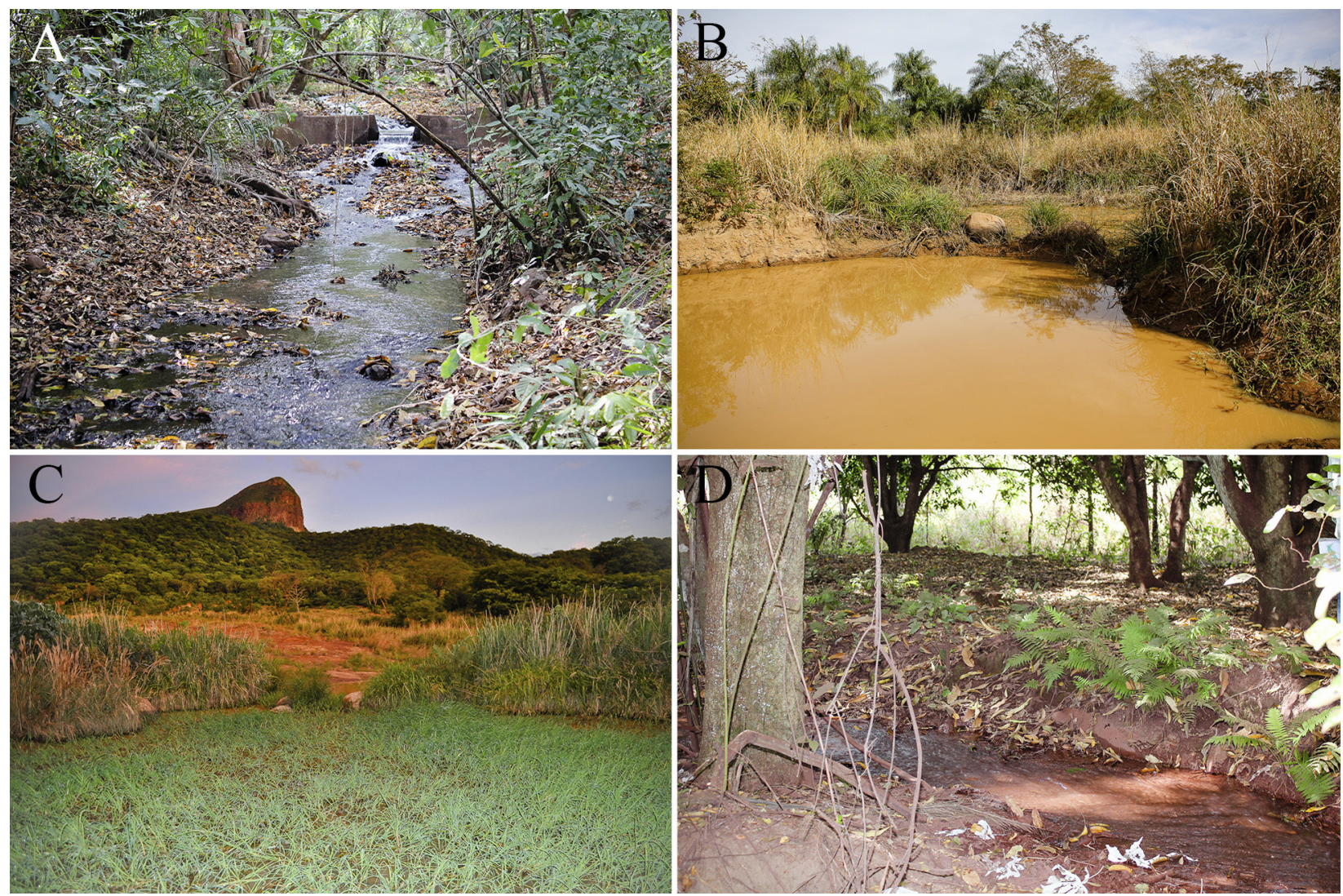

Figure 2. Some of the environments where anuran amphibians were sampled. A. Area 1, note the stone-bottomed stream, São Domingos, and leaf litter accumulation on its margins. B. Area 2, note the two permanent ponds surrounded by grassy vegetation and shrubs. C. Area 2, note one of the permanent ponds and the São Domingos hill, one of the elevations of Urucum massif, surrounding the PMP. D. Area 3, similar to area 1; note that the accumulation of leaf litter is reduced along the margins of the Piraputangas stream. 
the latitude and longitude where each voucher specimen was collected, so we use the geographic position of the approximate center of the PMP instead.

We released all but the voucher specimens at the end of each night, thus avoiding overestimating the number of specimens captured. Identification of specimens and range of snout-vent length (SVL) of adult individuals were based on AmphibiaWeb (2009), Norman (1994), Caramaschi and Cruz (1997), Narvaes and Rodrigues (2000), Achaval and Olmos (2007), Uetanabaro et al. (2008), Caramaschi (2010, 2006), Garda et al. (2010), de Sá et al. (2014), Gehara et al. (2014), and Piva et al. (2017). None of the species that we captured were listed as endangered or protected. A collection permit was granted by the Instituto Brasileiro do Meio Ambiente e dos Recursos Naturais Renováveis (IBAMA 20554-1). We deposited the vouchers in the Coleção Zoológica de Referência of the Universidade Federal de Mato Grosso do Sul (ZUFMS). Species nomenclature follows that of Frost (2020).

We made the following measurements (in $\mathrm{mm}$ ) for each voucher specimen: SVL, measured from the tip of the snout to the posterior margin of the vent; head length, measured diagonally from the posterior edge of the jaw articulation to the tip of the snout; and head width, the greatest width of the head, usually at about the level of the anterior edges of the tympani. All measurements followed the method described by Duellman (1970). In the species accounts, we adopted Savage's (2002) classification, which characterized adult frogs and toads by their SVL using the following categories: tiny $(<20 \mathrm{~mm})$, small (20-30 mm), moderate $(30-60 \mathrm{~mm})$, large $(60-$ $200 \mathrm{~mm})$, and giant $(>200 \mathrm{~mm})$. All measurements $( \pm$ $0.1 \mathrm{~mm}$ ) were taken using digital calipers. The voucher specimens comprised adult and juvenile individuals, as determined by the examination of gonads and secondary sex characters.

\section{Results}

We found 29 species of anurans in PMP (Table 1; Figs $3,4)$ during our field surveys, which represents approximately $30 \%$ of the anuran species known to occur in Mato Grosso do Sul and 50\% of the anurans recorded in semideciduous forests (Piva et al. 2017; Souza et al. 2017). This represents 14 genera and six families of anurans: Bufonidae (2 spp.), Dendrobatidae (1 sp.), Hylidae (10 spp.), Leptodactylidae (10 spp.), Microhylidae (4 spp.), and Phyllomedusidae (2 spp.). Dendropsophus minutus was the most frequently observed species (18.3\%), accounting for $22 \%$ and $32.1 \%$ of the total anurans found in Areas 1 and 3, respectively. We captured and released a single specimen of Boana punctata (Fig. 5A) on 25 January 2019 in Area 1 at 0800 h. This species is nocturnal and was probably taken while at rest. Although we found 126 specimens of Dendropsophus nanus (Boulenger, 1889) (Fig. 5B), none of these specimens were collected by our team during our formal field surveys and are not included in the main results below. In September 2017, we captured and added Ameerega picta to the list. A full list of species (including D. nanus) and individuals recorded in this study is presented in Table 1.

Bufonidae

\section{Rhinella diptycha (Cope, 1862a)}

Figure 3B

Material examined. BRAZIL • 1 q, SVL 53.95 mm; Mato Grosso do Sul, Corumbá, Parque Municipal de Piraputangas; ca $19^{\circ} 16^{\prime} \mathrm{S}, 057^{\circ} 38^{\prime} \mathrm{W}$; Jul. 2013; Alessandher Piva, Nelson R. de Albuquerque leg.; ZUFMS AMP-5153.

See also Table 1 for annual seasonality, survey areas where found, and total number of individuals found.

Identification. Large to giant toad (SVL 130-250 mm). Head short, wider than long $(18.13 \mathrm{~mm} \times 20.42 \mathrm{~mm})$ with snout truncate and vertical. Head with distinct cephalic crests and two well-developed, smooth parotid glands posterior to eyes. Pupil horizontal. Tympanum distinct. Interorbital area and area between tympanum and parotid gland smooth. Skin on dorsum rough, covered with blunt, spiny warts. In life, dorsum dark brown. Two interocular blotches dark brown. Upper surfaces of thigh and shank with dark-brown spots.

Remarks. We found seven specimens on the soil.

\section{Rhinella major (Müller \& Hellmich, 1936)}

Figure 3A

Material examined. BRAZIL • 1 , $55.84 \mathrm{~mm}$; Mato Grosso do Sul, Corumbá, Parque Municipal de Piraputangas; ca $19^{\circ} 16^{\prime} \mathrm{S}, 057^{\circ} 38^{\prime} \mathrm{W}$; 20 Mar. 2013; Alessandher Piva, Matheus O. Neves leg.; ZUFMS AMP-5144.

See also Table 1 for annual seasonality, survey areas where found, and total number of individuals found.

Identification. Moderate-sized to large toad (SVL 35.8$81.1 \mathrm{~mm})$. Head short, wider than long $(20.85 \mathrm{~mm} \times$ $22.26 \mathrm{~mm}$ ). Snout truncate in dorsal view. Pupil horizontal. Tympanum distinct, oval. Interorbital area and area between tympanum and parotid gland with granules. Two small parotid glands with granules posterior to eyes. Skin on dorsum rough, covered with blunt, spiny warts. In life, dorsum grayish with dark spots. Belly grayish with faded dark spots on anterior and middle regions.

Remarks. We found five specimens on the soil. Although the belly of this species has been described as not pigmented by Narvaes and Rodrigues (2009), in ZUFMS AMP-5144, it is pigmented with faded dark spots.

Dendrobatidae

\section{Ameerega picta (Tschudi, 1838)}

Figure 3C

Material examined. BRAZIL • 1 , $25.01 \mathrm{~mm}$; Mato Grosso do Sul, Corumbá, Parque Municipal de Piraputangas; right margin of the São Domingos stream; ca $19^{\circ} 16^{\prime}$ S, $057^{\circ} 38^{\prime} \mathrm{W}$; 13 Sep. 2017 ; Wener H. A. Moreno, Nelson R. de Albuquerque leg.; ZUFMS AMP-9022. 
Table 1. Annual seasonality, areas surveyed (Areas 1,2, and 3), and number ( $N$ ) of individuals sampled for each species of anuran recorded from August 2012 to July 2013 in PMP. Conservation status of the amphibians of PMP, according to the International Union for Conservation of Nature Red List (IUCN 2020): LC = Least Concern; DD = Data Deficient; NE = Not Evaluated.

\begin{tabular}{|c|c|c|c|c|c|c|c|c|c|c|c|c|c|c|c|}
\hline \multirow{2}{*}{ Family, species } & \multirow{2}{*}{ Area } & \multicolumn{12}{|c|}{ Months } & \multirow{2}{*}{$N$} & \multirow{2}{*}{$\begin{array}{l}\text { IUCN } \\
\text { status }\end{array}$} \\
\hline & & Aug. & Sep. & Oct. & Nov. & Dec. & Jan. & Feb. & Mar. & Apr. & May & Jun. & Jul. & & \\
\hline \multicolumn{16}{|l|}{ Bufonidae } \\
\hline Rhinella major & 2 & & $\bullet$ & & & & & $\bullet$ & $\bullet$ & & & & & 5 & NE \\
\hline Rhinella diptycha & $1,2,3$ & & - & & - & - & - & - & & - & & & & 7 & LC \\
\hline \multicolumn{16}{|l|}{ Dendrobatidae } \\
\hline Ameerega picta* & 1 & & $\bullet$ & & & & & & & & & & & 1 & $\mathrm{LC}$ \\
\hline \multicolumn{16}{|l|}{ Hylidae } \\
\hline Boana punctata* & 2 & & & & & & $\bullet$ & & & & & & & 1 & $\mathrm{LC}$ \\
\hline Boana raniceps & $1,2,3$ & $\bullet$ & $\bullet$ & $\bullet$ & $\bullet$ & $\bullet$ & $\bullet$ & $\bullet$ & $\bullet$ & $\bullet$ & $\bullet$ & $\bullet$ & $\bullet$ & 126 & LC \\
\hline Dendropsophus melanargyreus & 1 & & & $\bullet$ & & & & & & & & & & 1 & $\mathrm{LC}$ \\
\hline Dendropsophus minutus & $1,2,3$ & $\bullet$ & $\bullet$ & $\bullet$ & $\bullet$ & $\bullet$ & $\bullet$ & $\bullet$ & & $\bullet$ & $\bullet$ & $\bullet$ & $\bullet$ & 138 & LC \\
\hline Dendropsophus nanus & $1,2,3$ & $\bullet$ & $\bullet$ & $\bullet$ & $\bullet$ & $\bullet$ & & $\bullet$ & $\bullet$ & $\bullet$ & & $\bullet$ & & 26 & $\mathrm{LC}$ \\
\hline Pseudis platensis & 2 & $\bullet$ & $\bullet$ & $\bullet$ & $\bullet$ & $\bullet$ & $\bullet$ & $\bullet$ & $\bullet$ & $\bullet$ & $\bullet$ & & $\bullet$ & 43 & DD \\
\hline Scinax acuminatus & 2,3 & & $\bullet$ & $\bullet$ & & & & & $\bullet$ & & & $\bullet$ & & 4 & LC \\
\hline Scinax fuscovarius & $1,2,3$ & $\bullet$ & $\bullet$ & $\bullet$ & $\bullet$ & & & & & $\bullet$ & $\bullet$ & & & 24 & $\mathrm{LC}$ \\
\hline Scinaxnasicus & $1,2,3$ & - & - & • & - & - & & - & - & & & & - & 40 & $\mathrm{LC}$ \\
\hline Trachycephalus typhonius & 1 & & & $\bullet$ & & & & & $\bullet$ & $\bullet$ & $\bullet$ & & & 5 & $\mathrm{LC}$ \\
\hline \multicolumn{16}{|l|}{ Leptodactylidae } \\
\hline Adenomera diptyx & $1,2,3$ & - & $\bullet$ & $\bullet$ & - & - & $\bullet$ & - & & - & & $\bullet$ & & 27 & $\mathrm{LC}$ \\
\hline Leptodactylus chaquensis & 2 & $\bullet$ & $\bullet$ & $\bullet$ & $\bullet$ & & & $\bullet$ & $\bullet$ & $\bullet$ & $\bullet$ & $\bullet$ & $\bullet$ & 38 & $\mathrm{LC}$ \\
\hline Leptodactylus elenae & 3 & & & & & & $\bullet$ & & & & & & & 1 & $\mathrm{LC}$ \\
\hline Leptodactylus fuscus & 2,3 & & $\bullet$ & $\bullet$ & & & & $\bullet$ & & $\bullet$ & & & & 6 & $\mathrm{LC}$ \\
\hline Leptodactylus labyrinthicus & $1,2,3$ & & • & $\bullet$ & $\bullet$ & - & $\bullet$ & - & - & - & - & & & 56 & LC \\
\hline Leptodactylus mystacinus & 3 & & & & & & & $\bullet$ & & & & & & 1 & LC \\
\hline Leptodactylus podicipinus & $1,2,3$ & - & $\bullet$ & $\bullet$ & $\bullet$ & & $\bullet$ & & & • & - & & $\bullet$ & 101 & LC \\
\hline Physalaemus albonotatus & $1,2,3$ & $\bullet$ & $\bullet$ & $\bullet$ & $\bullet$ & $\bullet$ & $\bullet$ & $\bullet$ & $\bullet$ & $\bullet$ & $\bullet$ & & & 59 & $\mathrm{LC}$ \\
\hline Physalaemus biligonigerus & 2 & & • & & & & & & $\bullet$ & & & & & 7 & LC \\
\hline Physalaemus nattereri & 2 & & $\bullet$ & & & $\bullet$ & & & & & & & & 2 & LC \\
\hline \multicolumn{16}{|l|}{ Microhylidae } \\
\hline Chiasmocleis albopunctata & 3 & & & & $\bullet$ & & & & & & & & & 1 & $\mathrm{LC}$ \\
\hline Dermatonotus muelleri & 1 & & & & & & & $\bullet$ & & & & & & 1 & $\mathrm{LC}$ \\
\hline Elachistocleis matogrosso & $1,2,3$ & $\bullet$ & & & & & & & & & $\bullet$ & & & 2 & $\mathrm{LC}$ \\
\hline Elachistocleis corumbaensis & 1,2 & $\bullet$ & & & & $\bullet$ & & & & & $\bullet$ & & & 3 & $\mathrm{NE}$ \\
\hline \multicolumn{16}{|l|}{ Phyllomedusidae } \\
\hline Pithecopus azureus & 2 & & & $\bullet$ & $\bullet$ & $\bullet$ & $\bullet$ & $\bullet$ & & $\bullet$ & & & & 30 & DD \\
\hline Phyllomedusa sauvagii & 2 & & & & $\bullet$ & & & & & & & & & 1 & $\mathrm{LC}$ \\
\hline Number of species & & 12 & 17 & 16 & 15 & 12 & 10 & 15 & 11 & 14 & 11 & 6 & 6 & & \\
\hline Seasons & & Dry & & & Rainy & & & & & Dry & & & & & \\
\hline
\end{tabular}

${ }^{*}$ Ameerega picta (Dendrobatidae) and Boana punctata (Hylidae) were recorded by our team after the completion of our field surveys, and therefore appropriate data on abundance and seasonality are lacking for these two species (see comments in Methods).

See also Table 1 for annual seasonality, survey areas Hylidae where found, and total number of individuals found.

Identification. Small frog (SVL 24-26 mm). Head longer than wide $(8.50 \mathrm{~mm} \times 7.63 \mathrm{~mm})$ with snout truncate and rounded. Pupil rounded. Tympanum small, distinct. Fingers and toes bearing a pair of scute-like structures on the dorsal surface of each disk, lacking web. In life, dorsum dark brown, finely granulated, with one dorsolateral yellow-golden stripe on each side. Interocular blotch absent. Belly black with white to marble-bluish spots.

Remarks. ZUFMS-AMP 9022, unlike most Ameerega species (but see Forti et al. 2011), was found active at 19:30 h. The specimen contains follicles and oocytes in distinct stages.

Boana raniceps (Cope, 1862a)

Figure 3D, E

Material examined. BRAZIL • 1 § $59.39 \mathrm{~mm}, 1$,, 35.02 $\mathrm{mm}$; Mato Grosso do Sul, Corumbá, Parque Municipal de Piraputangas; ca $19^{\circ} 16^{\prime} \mathrm{S}, 057^{\circ} 38^{\prime} \mathrm{W}$; Jul. 2013; Alessandher Piva, Nelson R. de Albuquerque leg.; ZUFMS AMP-5168, ZUFMS AMP-5170.

See also Table 1 for annual seasonality, survey areas where found, and total number of individuals found.

Identification. Moderate, elongate tree frog, with long hindlimbs (SVL 55-60 mm). Head longer than wide $(24.67 \mathrm{~mm} \times 17.55 \mathrm{~mm}, 13.47 \mathrm{~mm} \times 10.40 \mathrm{~mm})$, with 

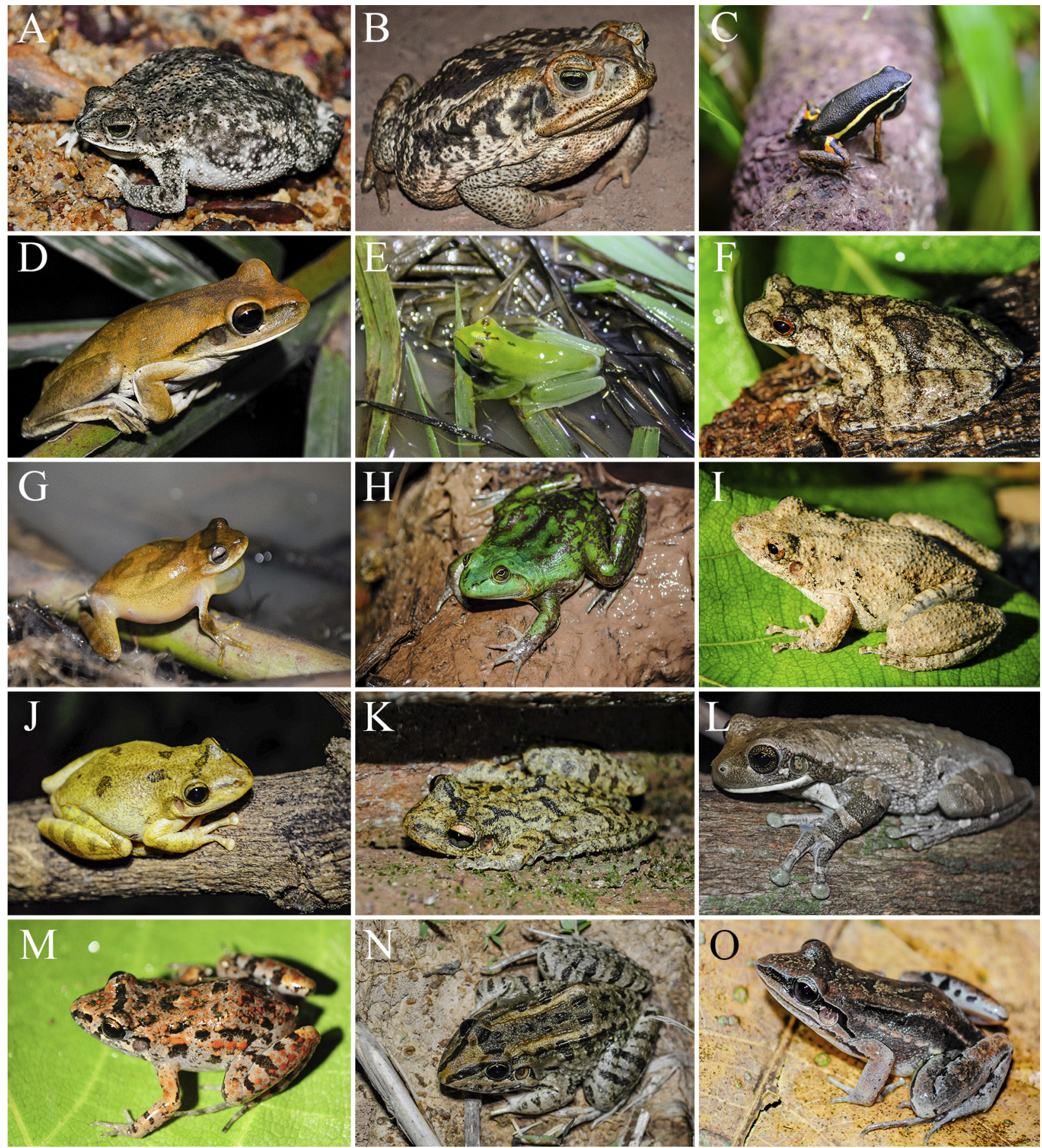

Figure 3. Anurans captured during our surveys. BUFONIDAE: A. Rhinella major. B. Rhinella diptycha. HYLIDAE: C. Ameerega picta. D. Boana raniceps. E. Boana raniceps (juvenile). F. Dendropsophus melanargyreus. G. Dendropsophus minutus. H. Pseudis platensis. I. Scinax acuminatus. J. Scinax fuscovarius. K. Scinax nasicus. L. Trachycephalus typhonius. M. Adenomera diptyx. LEPTODACTYLIDAE: N. Leptodactylus chaquensis. $\mathbf{O}$. Leptodactylus elenae. Photos C, E by Nelson R. de Albuquerque; all others by Alessandher Piva.

snout rounded in dorsal and profile views. Pupil horizontal. Tympanum large, distinct. Skin on dorsum smooth. Skin on belly finely granular. In life, dorsum yellow-brown. Dorsum of female with continuous series of brown irregular blotches along sagittal plane. Interocular blotch present in female. Posterior flank with narrow, brownish, vertical bars. Belly immaculate. Anterior and posterior surfaces of thigh and posterior face of shank marked with transverse dark bars. Toes with adhesive disks. Fingers II, III, and IV webbed only at base, whereas finger I lacks web. The specimen (not captured) shown in Figure 3E was possibly juvenile; its dorsum was green with an anterior dark blotch on its front, the interocular area had with a $\mathrm{V}$-shaped line, and there was a small, dark-brown spot on each supraocular.

Remarks. With 126 encounters during the entire field survey, this species was the second most frequently seen species (16.7\%). It occupied all six types of substrate we identified in PMP.

\section{Dendropsophus melanargyreus (Cope, 1887)}

Figure 3F 
Material examined. BRAZIL • 1 , $31.63 \mathrm{~mm}$; Mato Grosso do Sul, Corumbá, Parque Municipal de Piraputangas; ca $19^{\circ} 16^{\prime} \mathrm{S}, 057^{\circ} 38^{\prime} \mathrm{W}$; 30 Oct. 2012; Alessandher Piva, Nelson R. de Albuquerque leg.; ZUFMS AMP-5162.

See also Table 1 for annual seasonality, survey areas where found, and total number of individuals found.

Identification. Moderate-sized tree frog (SVL 32-37 $\mathrm{mm})$. Head as long as wide $(9.37 \mathrm{~mm} \times 9.35 \mathrm{~mm})$ with snout truncate and rounded. Pupil horizontal. Tympanum distinct. In life, dorsum brownish with tubercles poorly developed. Interocular blotch large, dark. Belly cream. Fingers moderately webbed. Toes I, II, III, and V almost fully webbed to bases of disks. Upper surfaces of thigh and shank with transverse dark bars. Anterior and posterior surfaces of thigh with dark-brown stripes.

Remarks. We found a single specimen and it was perched as high as $150 \mathrm{~cm}$ above the ground.

\section{Dendropsophus minutus (Peters, 1872)}

Figure $3 \mathrm{G}$

Material examined. BRAZIL • 1 ô, $15.94 \mathrm{~mm}$; Mato Grosso do Sul, Corumbá, Parque Municipal de Piraputangas; ca $19^{\circ} 16^{\prime} \mathrm{S}, 057^{\circ} 38^{\prime} \mathrm{W}$; Jul. 2013; Alessandher Piva, Nelson R. de Albuquerque leg.; ZUFMS AMP-5141.

See also Table 1 for annual seasonality, survey areas where found, and total number of individuals found.

Identification. Small tree frog (SVL 21-28 mm). Head short, longer than wide $(6.33 \mathrm{~mm} \times 5.17 \mathrm{~mm})$, with snout rounded in dorsal and profile views. Pupil horizontal. Tympanum indistinct. Skin on dorsum smooth. Fingers and toes with adhesive disks. Toes moderately webbed. In life, dorsum orange-brown, with a pair of darker brown, hourglass-shaped stripes. Interocular blotch large, dark brown. Belly whitish-yellow. Upper surface of thighs and shanks orange tan and with scattered, small, dark spots. Upper surface of shanks with narrow, brown bars.

Remarks. This species occupied all the six types of substrate identified (i.e., aquatic, arboreal, grassy, rocky, leaf litter, and soil) in PMP. Among the 138 specimens found, some were perched on tree trunks as high as 180 $\mathrm{cm}$ above the ground.

\section{Pseudis platensis Gallardo, 1961}

Figure $3 \mathrm{H}$

Material examined. BRAZIL • 1 gravid $+; 47.2 \mathrm{~mm}$; Mato Grosso do Sul, Corumbá, Parque Municipal de Piraputangas; ca $19^{\circ} 16^{\prime} \mathrm{S}, 057^{\circ} 38^{\prime} \mathrm{W}$; Jul. 2013; Alessandher Piva, Nelson R. de Albuquerque leg.; ZUFMS AMP-5161.

See also Table 1 for annual seasonality, survey areas where found, and total number of individuals found.

Identification. Moderate-sized to large shrinking frog (SVL 34-76.4 mm). Head slightly shorter than wide $(19.02 \mathrm{~mm} \times 21.08 \mathrm{~mm})$ with snout rounded. Pupil horizontal. Tympanum large and distinct. Skin on dorsum smooth. In life, dorsum dark green, with stripes and mottling. Interocular blotch absent. Belly white, with dark spots on middle and posterior regions. Upper surfaces of thigh and shank mottled with brown. Contrary to other hylids found at PMP, the head of Pseudis platensis is small in comparison to the body, the protuberant eyes are in a dorsolateral position and the toes are fully webbed.

Remarks. All 43 specimens recorded were in one of the permanent ponds.

\section{Scinax acuminatus (Cope, 1862a)}

Figure 3I

Material examined. BRAZIL • 1 gravid ๆ, $43.43 \mathrm{~mm}$; Mato Grosso do Sul, Corumbá, Parque Municipal de Piraputangas; ca $19^{\circ} 16^{\prime} \mathrm{S}, 057^{\circ} 38^{\prime} \mathrm{W}$; 30 Oct. 2012; Alessandher Piva, Nelson R. de Albuquerque leg.; ZUFMS AMP-5164.

See also Table 1 for annual seasonality, survey areas where found, and total number of individuals found.

Identification. Moderate-sized frog (SVL 40-46 mm). Head nearly as long as wide $(15.75 \mathrm{~mm} \times 15.41 \mathrm{~mm})$, with snout rounded in dorsal and profile views. Pupil horizontal. Tympanum distinct. Skin on dorsum glandular. Fingers and toes with adhesive disks. Toes moderately webbed. In life, dorsum light gray, with a few small, dark, lateral lines. Belly cream with small, brown spots. Upper surfaces of thigh and shank mottled with narrow, gray crossbands.

Remarks. One of the four specimens found was on the soil, but the other three were perched as high as $150 \mathrm{~cm}$ above the ground.

\section{Scinax fuscovarius (Lutz, 1925)}

Figure 3J

Material examined. BRAZIL • 1 gravid $q, 42.53 \mathrm{~mm}$; Mato Grosso do Sul, Corumbá, Parque Municipal de Piraputangas; ca $19^{\circ} 16^{\prime} \mathrm{S}, 057^{\circ} 38^{\prime} \mathrm{W}$; 24 Jul. 2012; Alessandher Piva, Nelson R. de Albuquerque leg.; ZUFMS AMP-5160.

See also Table 1 for annual seasonality, survey areas where found, and total number of individuals found.

Identification. Moderate-sized tree frog (SVL 47-50 $\mathrm{mm})$. Head longer than wide $(18.30 \mathrm{~mm} \times 14.32 \mathrm{~mm})$. Pupil horizontally elliptical. Eyes moderate. Tympanum distinct, large. Skin on dorsum smooth. Fingers and toes with adhesive disks. Toes moderately webbed. In life, dorsum yellowish and with four darker spots. Two small interocular blotches, dark. Belly whitish. Thighs orange tan. Upper surfaces of thigh and shank with transverse brown bars. Posterior thigh with brown spots.

Remarks. One of the specimens was found on a rocky substrate, six were found on soil, seven on leaf litter, and 10 were perched as high as $150 \mathrm{~cm}$ above the ground.

\section{Scinax nasicus (Cope, 1862a)}

Figure $3 \mathrm{~K}$

See also Table 1 for annual seasonality, survey areas where found, and total number of individuals found.

Material examined. BRAZIL • $1 \hat{\jmath}, 43.43 \mathrm{~mm}$; Mato Grosso do Sul, Corumbá, Parque Municipal de Pirapu- 
tangas; ca $19^{\circ} 16^{\prime} \mathrm{S}, 057^{\circ} 38^{\prime} \mathrm{W}$; Sep. 2013; A. Piva, N. R. Albuquerque leg.; (ZUFMS AMP-5157).

Identification. Moderate-sized frog (SVL 27-35 mm). Head longer than broad $(17.97 \mathrm{~mm} \times 13.47 \mathrm{~mm})$. Snout rounded in dorsal and profile views. Pupil horizontal. Tympanum distinct. Skin on dorsum smooth. Fingers and toes with adhesive disks. Toes, except for the first, moderately webbed. In life, dorsum yellowish-green with some dark, x-shaped marks. Large interocular blotch present. Belly whitish, immaculate. Upper surfaces of thigh and shank with transverse, dark-brown bars.

Remarks. This species occupied all six types of substrates identified, with some specimens perched as high as $150 \mathrm{~cm}$ above the ground. The SVL of the voucher specimen, ZUFMS AMP-5157, is larger than previously reported (Cei 1980; Achaval and Olmos 2017).

\section{Trachycephalus typhonius (Linnaeus, 1758)} Figure 3L

See also Table 1 for annual seasonality, survey areas where found, and total number of individuals found.

Material examined. BRAZIL • 1 o, $69.97 \mathrm{~mm}$; Mato Grosso do Sul, Corumbá, Parque Municipal de Piraputangas; ca $19^{\circ} 16^{\prime} \mathrm{S}, 057^{\circ} 38^{\prime} \mathrm{W}$; Jul. 2013; Alessandher Piva, Nelson R. de Albuquerque leg.; ZUFMS AMP-5148.

Identification. Large, robust tree frog (SVL 70-114 mm). Head slightly shorter than wide $(20.86 \mathrm{~mm} \times 21.22 \mathrm{~mm})$, with paired lateral vocal sacs. Snout semicircular in dorsal view and rounded in profile. Pupil horizontal. Tympanum distinct. Skin on dorsum thick, glandular, and tuberculate. Skin on belly finely granular. Fingers and toes with adhesive disks. Toes moderately webbed. In life, dorsum brown with some dark-brown blotches. Flank uniform not mottled. Belly cream, immaculate. Upper surfaces of arm, thigh, and shank mottled with brown.

Remarks. We found the five specimens perched as high as $200 \mathrm{~cm}$ above the ground.

\section{Leptodactylidae}

\section{Adenomera diptyx (Linnaeus, 1758)}

Figure $3 \mathrm{M}$

See also Table 1 for annual seasonality, survey areas where found, and total number of individuals found.

Material examined. BRAZIL • 1 ô, $22.12 \mathrm{~mm}$; Mato Grosso do Sul, Corumbá, Parque Municipal de Piraputangas; ca $19^{\circ} 16^{\prime} \mathrm{S}, 057^{\circ} 38^{\prime} \mathrm{W}$; 27 Sep. 2012; Alessandher Piva, Nelson R. de Albuquerque leg.; ZUFMS AMP-5150.

Identification. Small frog (SVL 22-25 mm). Head longer than broad $(10.16 \mathrm{~mm} \times 7.42 \mathrm{~mm})$. Pupil horizontal. Tympanum distinct. Skin on dorsum with longitudinal rows of small tubercles. Fingers and toes lack adhesive disks. Toes not webbed. In life, dorsum brownish with several dark blotches. Belly cream, immaculate. Upper surfaces of arm, thigh, and shank mottled with black

Remarks. All the 27 specimens found were on soil.

\section{Leptodactylus chaquensis Cei, 1950}

Figure 3N

Material examined. BRAZIL • 1 o, $77.06 \mathrm{~mm}$; Mato Grosso do Sul, Corumbá, Parque Municipal de Piraputangas; ca $19^{\circ} 16^{\prime} \mathrm{S}, 057^{\circ} 38^{\prime} \mathrm{W}$; Jul. 2013; Alessandher Piva, Nelson R. de Albuquerque leg.; ZUFMS AMP-5163.

See also Table 1 for annual seasonality, survey areas where found, and total number of individuals found.

Identification. Large frog (SVL 65.4-97.6 mm). Head longer than wide $(28.80 \mathrm{~mm} \times 26.47 \mathrm{~mm})$. Pupil horizontal. Snout rounded in dorsal view and in profile. Tympanum distinct. Skin of dorsum smooth, with pair of complete dorsal folds and dorsolateral folds. Fingers and toes lack adhesive disks and web. Finger I in the examined material with two nuptial spines. In life, dorsum brownish with series of dark blotches. Dark, triangular, interocular spot present. Yellowish glandular parches on flank and groin. One pair of dorsolateral black stripes runs from behind the eye to the groin. Belly uniformly light. Upper surfaces of thigh and shank mottled with dark crossbands.

Remarks. We found all the 38 specimens in permanent ponds or on the soil.

\section{Leptodactylus elenae Heyer, 1978}

Figure $3 \mathrm{O}$

Material examined. BRAZIL • 1 ㅇ, $36.78 \mathrm{~mm}$; Mato Grosso do Sul, Corumbá, Parque Municipal de Piraputangas; ca $19^{\circ} 16^{\prime} \mathrm{S}, 057^{\circ} 38^{\prime} \mathrm{W}$; 29 Aug. 2012; Alessandher Piva, Nelson R. de Albuquerque leg.; ZUFMS AMP-5159.

See also Table 1 for annual seasonality, survey areas where found, and total number of individuals found.

Identification. Moderate-sized frog (SVL 37.9-48.6 $\mathrm{mm})$. Head longer than wide $(14.75 \mathrm{~mm} \times 13.37 \mathrm{~mm})$. Pupil horizontal. Tympanum distinct. Skin of dorsum smooth with longitudinal row of small tubercles limited to lateral region. Fingers and toes lack adhesive disks. Toes not webbed. In life, dorsum tan, with series of brown and dark spots. Light upper lip stripe present. Belly cream, immaculate. Upper surfaces of thigh and shank with horizontal dark stripes. Posterior and anterior surfaces of thigh with brown stripe.

Remarks. We found only one specimen and it was on the soil.

\section{Leptodactylus fuscus (Schneider, 1799)}

Figure 4A

Material examined. BRAZIL • 1 q, $40.87 \mathrm{~mm}$; Mato Grosso do Sul, Corumbá, Parque Municipal de Piraputangas; ca $19^{\circ} 16^{\prime} \mathrm{S}, 057^{\circ} 38^{\prime} \mathrm{W}$; 27 Sep. 2012; Alessandher Piva, Nelson R. de Albuquerque leg.; ZUFMS AMP-5165.

See also Table 1 for annual seasonality, survey areas where found, and total number of individuals found.

Identification. Moderate-sized frog (SVL 32.4-56.3 $\mathrm{mm})$. Head longer than wide $(18.03 \mathrm{~mm} \times 14.05 \mathrm{~mm})$. 

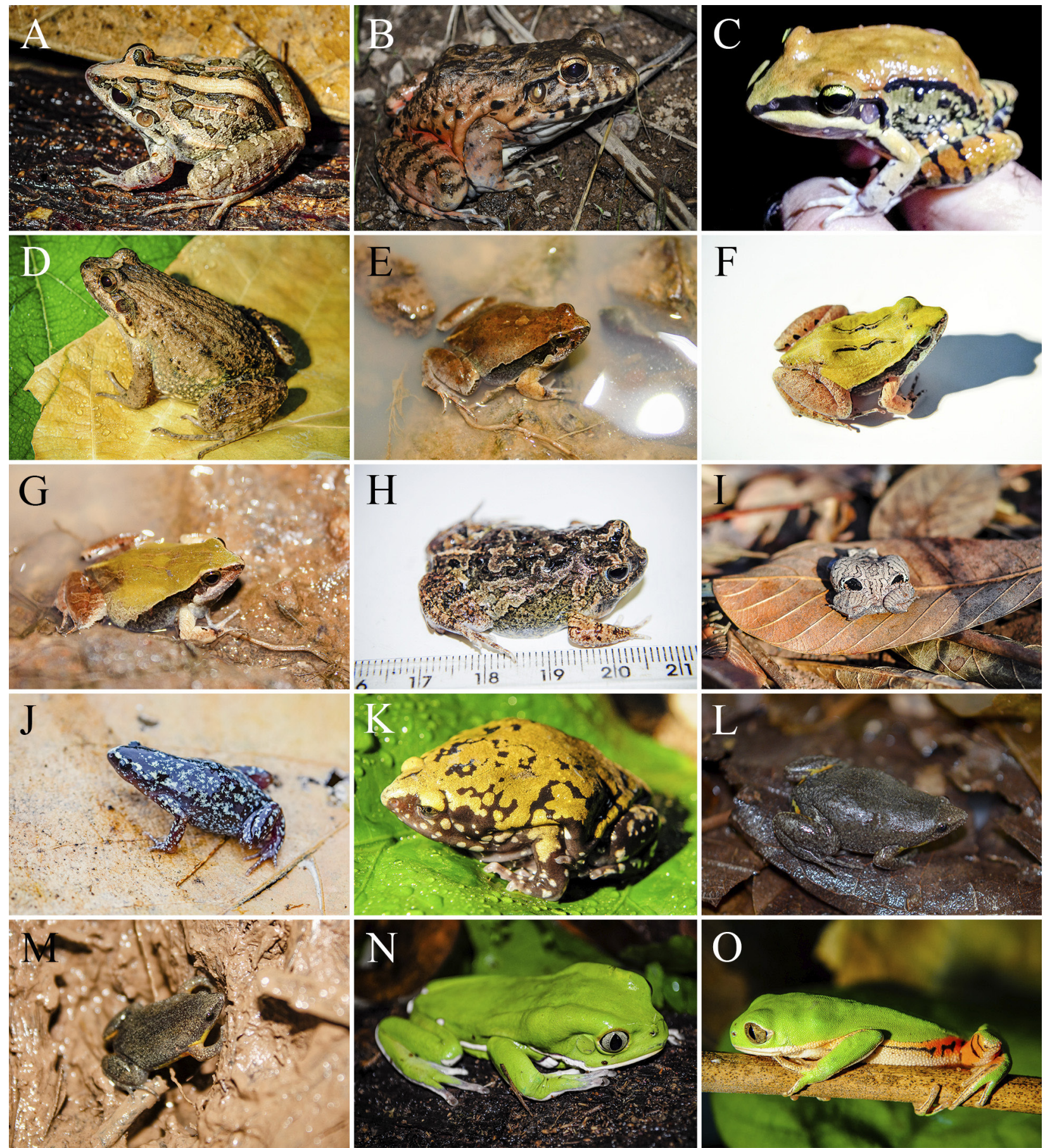

Figure 4. Anurans captured during our surveys. LEPTODACTYLIDAE: A. Leptodactylus fuscus. B. Leptodactylus labyrinthicus. C. Leptodactylus mystacinus. D. Leptodactylus podicipinus. E. Physalaemus albonotatus. F. Physalaemus albonotatus. G. Physalaemus albonotatus H. Physalaemus biligonigerus. I. Physalaemus nattereri. J. Chiasmocleis albopunctata. K. Dermatonotus muelleri. L. Elachistocleis corumbaensis. M. Elachistocleis matogrosso. N. Phyllomedusa sauvagii. O. Pithecopus azureus. Photos E-G, J, L, M by Nelson R. de Albuquerque; others by Alessandher Piva.

Snout spatulate. Pupil horizontal. Tympanum distinct. Skin of dorsum smooth, with two developed dorsal folds and a pair of well-developed dorsolateral folds. Fingers and toes lack adhesive disks and web. In life, dorsum brownish with series of brown blotches. Broad light mid-dorsal stripe extends from snout to posterior end of dorsum. A pair of dorsolateral black stripes runs from behind the eye to the groin. Light upper lip stripe distinct. Interocular spot absent. Belly creamy-white. Upper surfaces of thigh and shank mottled with brown crossbands.
Remarks. The six specimens were found on aquatic, soil, and rocky substrates. De Sá et al. (2014) noted that individuals of Leptodactylus fuscus usually lack the presence of a light mid-dorsal stripe, although it is present in ZUFMS AMP-5165.

\section{Leptodactylus labyrinthicus (Spix, 1824)}

Figure 4B

Material examined. BRAZIL • 1 gravid $\odot ; 81.51 \mathrm{~mm}$; Mato Grosso do Sul, Corumbá, Parque Municipal de Pi- 

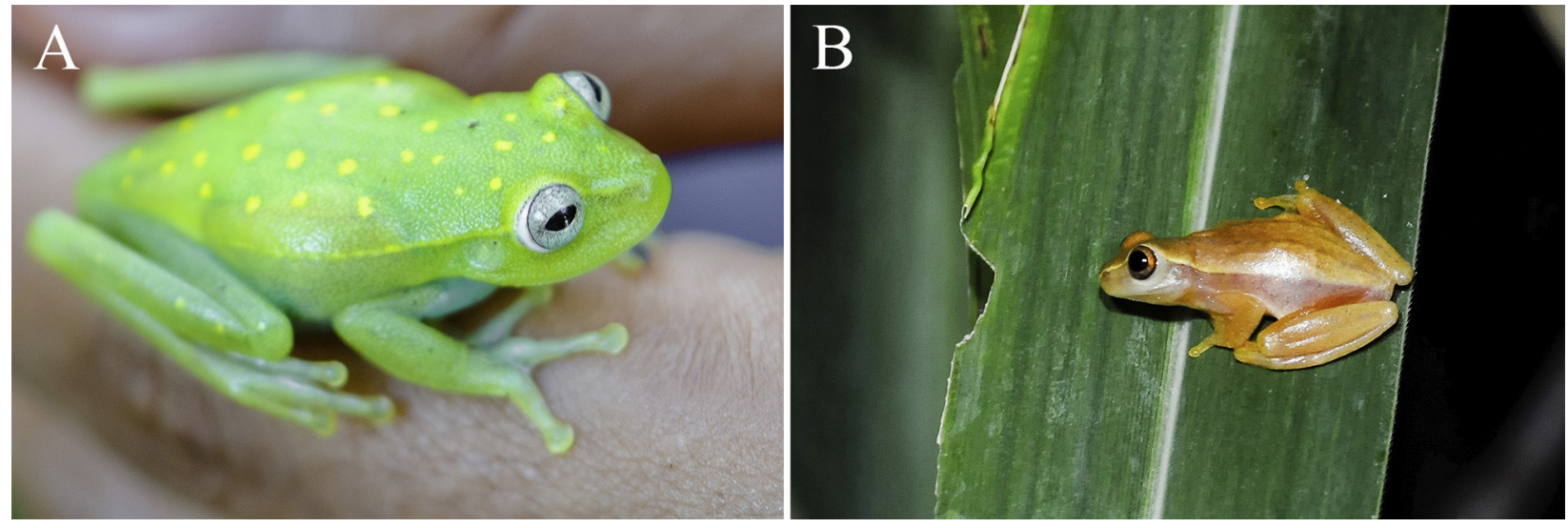

Figure 5. General view in life of Boana punctata and Dendropsophus nanus from Parque Municipal de Piraputangas, Mato Grosso do Sul, Brazil (specimens not collected). A. B. punctata. B. D. nanus. Photos by Nelson R. de Albuquerque.

raputangas; ca $19^{\circ} 16^{\prime} \mathrm{S}, 057^{\circ} 38^{\prime} \mathrm{W}$; Jul. 2013; Alessandher Piva, Nelson R. de Albuquerque leg.; ZUFMS AMP-5142.

See also Table 1 for annual seasonality, survey areas where found, and total number of individuals found.

Identification. Large frog, with heavy hindlimbs (SVL $110.6-188 \mathrm{~mm})$. Head slightly longer than wide (35.30 $\mathrm{mm} \times 34.79 \mathrm{~mm}$ ). Snout rounded. Pupil horizontal. Tympanum large, distinct. Skin of dorsum smooth. Fingers and toes lack adhesive disks. Toes not webbed. In life, dorsum and flank brownish, with series of dark spots. Interocular blotch absent. Belly light, with dark vermiculations. Groin and posterior surface of thigh orange. Upper surfaces of thigh and shank with transverse dark bars. Posterior and anterior surfaces of thigh with dark spots.

Remarks. We found the 56 specimens on aquatic, leaf litter, rocky, and soil substrates.

\section{Leptodactylus mystacinus (Burmeister, 1861) Figure 4C}

Material examined. BRAZIL • 1 , $54.44 \mathrm{~mm}$; Mato Grosso do Sul, Corumbá, Parque Municipal de Piraputangas; ca $19^{\circ} 16 \mathrm{~S}, 057^{\circ} 38^{\prime} \mathrm{W}$; 20 Feb. 2013; Alessandher Piva, Nelson R. de Albuquerque leg.; ZUFMS AMP-5158.

See also Table 1 for annual seasonality, survey areas where found, and total number of individuals found.

Identification. Moderate-sized to large frog (SVL 46.6$67.1 \mathrm{~mm})$. Head longer than wide $(23.18 \mathrm{~mm} \times 19.85$ $\mathrm{mm})$. Snout rounded in dorsal view and profile. Pupil horizontal. Tympanum distinct. Fingers and toes without adhesive disks and web. Skin of dorsum smooth. In life, dorsum golden-yellow. Upper lip with a distinct light stripe. One pair of dorsolateral black stripes runs from behind the tympanum to the groin. Interocular blotch absent. Belly cream, immaculate. Upper surfaces of thigh and shank with dark narrow crossbands. Flank and posterior surface of thighs with small white spots.

Remarks. The single specimen collected was found on leaf litter. According to Heyer et al. (2003), the head of L. mystacinus is as wide as long (but see ZUFMS AMP5158 and De-Carvalho et al. 2008). Together with Kwet et al. (2010), Heyer et al. (2003) mentioned the extensive variation in the dorsal color pattern of this species, which varies from yellowish, gray, or orange-brown to copper. The dorsum can be uniformly colored, as in ZUFMS AMP-5158), or with small dark spots.

\section{Leptodactylus podicipinus (Cope, 1862b)}

Figure 4D

Material examined. BRAZIL • 1 gravid $\odot, 45.89 \mathrm{~mm}$; Mato Grosso do Sul, Corumbá, Parque Municipal de Piraputangas; ca $19^{\circ} 16^{\prime} \mathrm{S}, 057^{\circ} 38^{\prime} \mathrm{W}$; 30 Oct. 2012; Alessandher Piva, Nelson R. de Albuquerque leg.; ZUFMS AMP-5154.

See also Table 1 for annual seasonality, survey areas where found, and total number of individuals found.

Identification. Small to moderate-sized frog (SVL 24.5$54 \mathrm{~mm}$ ). Head longer than wide (14.83 mm $\times 7.09 \mathrm{~mm})$. Snout rounded in dorsal and profile views. Pupil horizontal. Tympanum distinct. Fingers and toes lack adhesive disks and web. Skin of dorsum smooth, with two short, not well-developed dorsolateral folds. In life, dorsum brown. Light posterior lip stripe present. Yellowish glandular patches on flanks and groin. One pair of dorsolateral black stripes runs from behind the eye to the groin. Dark interocular spot present. Belly mottled with small white spots. Posterior surfaces of thigh and shank mottled with dark, narrow crossbands.

Remarks. The 101 specimens found were seen most frequently in areas predominantly characterized by permanent and ephemeral ponds. We noted oocytes and follicles in various stages in ZUFMS AMP-5154.

\section{Physalaemus albonotatus (Steindachner, 1864) Figure 4E-G}

Material examined. BRAZIL • $1 \hat{\jmath}, 11.87 \mathrm{~mm}$; Mato Grosso do Sul, Corumbá, Parque Municipal de Piraputangas; ca $19^{\circ} 16^{\prime} \mathrm{S}, 057^{\circ} 38^{\prime} \mathrm{W}$; Jul. 2013; Alessandher Piva, Nelson R. de Albuquerque leg.; ZUFMS AMP-5152.

See also Table 1 for annual seasonality, survey areas where found, and total number of individuals found.

Identification. Small to moderate-sized frog (SVL 
26.4-34.1 mm). Head longer than wide $(9.98 \mathrm{~mm} \times 7.95$ $\mathrm{mm})$. Snout rounded in dorsal view and in profile. Pupil horizontal. Tympanum distinct. Fingers and toes without adhesive disks and web. Skin of dorsum covered with blunt warts. In life, dorsum brownish with lighter spot on anterior region. Large dark postorbital stripe extends from posterior corner of the orbit to the groin. Interocular spot present. Vocal sac dark. Belly cream with brownish blotches. Upper surfaces of thigh and shank mottled with brown crossbands. The dorsum of uncaptured specimen shown in Figure $3 \mathrm{~F}$ was yellow-green with two brownish stripes margined with black, two small brownish spots on the interocular area, also margined with black, and a thin mid-longitudinal light stripe from the snout to the vent; a very similar specimen (Fig. 3G) differs from that shown in Figure 3E in having a greenish dorsum.

Remarks. We found the 59 specimens on aquatic, leaf litter, rocky, and soil substrates.

\section{Physalaemus biligonigerus (Cope, 1861)}

\section{Figure $4 \mathrm{H}$}

Material examined. BRAZIL • 1 o, $33.62 \mathrm{~mm}$; Mato Grosso do Sul, Corumbá, Parque Municipal de Piraputangas; ca $19^{\circ} 16^{\prime} \mathrm{S}, 057^{\circ} 38^{\prime} \mathrm{W}$; 27 Sep. 2012; Alessandher Piva, Nelson R. de Albuquerque leg.; ZUFMS AMP-5147.

See also Table 1 for annual seasonality, survey areas where found, and total number of individuals found.

Identification. Small to moderate-sized frog (SVL 25$40 \mathrm{~mm})$. Head shorter than wide $(14.01 \mathrm{~mm} \times 15.43 \mathrm{~mm})$. Snout slightly truncate in dorsal view and sloped in profile. Pupil horizontal. Tympanum distinct. Fingers and toes lack adhesive disks and web. Skin of dorsum and thigh covered with blunt warts. Posterior belly finely granular. In life, dorsum brownish, with brown stripes of irregular shape and width, tending to form an omegashaped $(\Omega)$ mark on the scapular region, with lighter central area. Head ornamented with dark and light alternate vertical bar, and flanks devoid of defined pattern. Interocular spot T-shaped. Belly creamy, immaculate. Upper surfaces of thigh and shank mottled with dark crossbands.

Remarks. We found seven specimens in a temporary pool.

\section{Physalaemus nattereri (Steindachner, 1863)}

Figure 4I

Material examined. BRAZIL $\bullet 1$ ô, $31.75 \mathrm{~mm}$; Mato Grosso do Sul, Corumbá, Parque Municipal de Piraputangas; ca $19^{\circ} 16^{\prime} \mathrm{S}, 057^{\circ} 38^{\prime} \mathrm{W}$; 27 Sep. 2012; A. Piva, M. O. Neves leg.; ZUFMS AMP-5145. 1 gravid + , 35.16 mm; Mato Grosso do Sul, Corumbá, Parque Municipal de Piraputangas; ca $19^{\circ} 16^{\prime} \mathrm{S}, 057^{\circ} 38^{\prime} \mathrm{W}$; 19 Dec. 2012; A. Piva, M. O. Neves leg.; ZUFMS AMP-5146

See also Table 1 for annual seasonality, survey areas where found, and total number of individuals found.

Identification. Moderate-sized frog (SVL 42.8-56.4 $\mathrm{mm})$. Head slightly shorter than wide $(12.75 \mathrm{~mm} \times 13.20$ $\mathrm{mm}{ }^{\lambda}, 13.69 \mathrm{~mm} \times 14.76 \mathrm{~mm}$ ) ). Snout rounded in dorsal view and in profile. Pupil horizontal. Tympanum distinct. Fingers and toes lack adhesive disks and web. Skin of dorsum smooth. Posterior belly finely granular. In life, dorsum brownish, with lighter spot on anterior region and two "false eyes" on its rear. Large dark postorbital stripe extends from posterior corner of the orbit to the groin. Small interocular spot present. Vocal sac black. Belly cream, immaculate. Upper surfaces of thigh and shank mottled with brown crossbands.

Remarks. We collected two specimens in a temporary pool. We noted follicles in various stages in ZUFMS AMP-5146.

Microhylidae

\section{Chiasmocleis albopunctata (Boettger, 1885)}

Figure 4J

Material examined. BRAZIL • 1 gravid $\odot, 28.24 \mathrm{~mm}$; Mato Grosso do Sul, Corumbá, Parque Municipal de Piraputangas; ca $19^{\circ} 16^{\prime} \mathrm{S}, 057^{\circ} 38^{\prime} \mathrm{W}$; 3 Dec. 2012 ; Alessandher Piva, Nelson R. de Albuquerque leg.; ZUFMS AMP-5156.

See also Table 1 for annual seasonality, survey areas where found, and total number of individuals found.

Identification. Small to moderate-sized, globular frog (SVL 23.2-38 mm). Head small, slightly shorter than wide $(7.23 \mathrm{~mm} \times 7.84 \mathrm{~mm})$. Pupil rounded. Tympanum absent. Postorbital fold present. Snout rounded in dorsal and lateral profiles. Fingers and toes without adhesive disks and web. Lateral sides of fingers and toes lack spines. Skin of dorsum smooth. In life, dorsum and flanks dark to dark brown, with several white, irregularly distributed spots. Interocular spot absent. Belly grayish, with small, white, irregularly disposed spots. Upper surfaces of arms, flanks, and limbs also covered by white spots.

Remarks. We found a single specimen and it was on the soil.

\section{Dermatonotus muelleri (Boettger, 1885)}

\section{Figure 4K}

Material examined. BRAZIL • 1 , $32.72 \mathrm{~mm}$; Mato Grosso do Sul, Corumbá, Parque Municipal de Piraputangas; ca $19^{\circ} 16^{\prime} \mathrm{S}, 057^{\circ} 38^{\prime} \mathrm{W}$; 18 Fev. 2013; Alessandher Piva, Nelson R. de Albuquerque leg.; ZUFMS AMP-5149.

See also Table 1 for annual seasonality, survey areas where found, and total number of individuals found.

Identification. Moderate-sized to large, globular frog (SVL 58-64 mm). Head small, shorter than wide (12.81 $\mathrm{mm} \times 15.62$ ). Pupil rounded. Tympanum absent. Snout truncate in dorsal view and rounded in profile. Fingers and toes lack adhesive disks and web. Skin of dorsum smooth. In life, dorsum olive-green, spotted with dark, irregular, dorsal and lateral blotches. Interocular spot absent. Belly dark and scattered with pale yellow spots. Arms, flanks, and limbs dark, mottled with irregular white blotches. 
Remarks. We found a single specimen and it was on the soil.

\section{Elachistocleis corumbaensis Piva, Caramaschi \&} Albuquerque, 2017

Figure 4L

Material examined. BRAZIL • 3 $\curvearrowright, 31.4 \mathrm{~mm}, 30.8 \mathrm{~mm}$, $26.9 \mathrm{~mm}$; Mato Grosso do Sul, Corumbá, Parque Municipal de Piraputangas; ca $19^{\circ} 16^{\prime} \mathrm{S}, 057^{\circ} 38^{\prime} \mathrm{W}$; 30 Nov. 2013 ; A. Piva, U. Caramaschi, Nelson R. de Albuquerque leg.; MNRJ 91001, ZUFMS-AMP-923, ZUFMS-AMP-924.

See also Table 1 for annual seasonality, survey areas where found, and total number of individuals found.

Identification. Small to moderate-sized oval frog (SVL 26.9-40.3 mm). Head small, slightly shorter than wide $(6.7 \mathrm{~mm} \times 7.3 \mathrm{~mm}, 6.8 \mathrm{~mm} \times 7.5 \mathrm{~mm}, 5.52 \mathrm{~mm} \times 6.2$ $\mathrm{mm})$. Snout subelliptical in dorsal view and protruding in profile. Pupil rounded. Tympanum indistinct. Fingers and toes lack adhesive disks and web. Skin of dorsum slightly rough. In life, dorsum grayish with scattered minute white dots; two small yellow spots on anterior dorsum. Vocal sac of ZUFMS-924 darker than venter. Interocular spot absent. Limit between dorsum and belly made distinct with the presence of white spots. Belly and inguinal region gray, with white spots; large, irregular light-yellow spot on anterior thigh; large, irregular, lightyellow spots on groin; narrow, irregular, light-orange stripe on posterior thigh; irregular, light-orange spots on proximal internal surface of shank.

Remarks. ZUFMS-AMP 923 bears a thin, mid-longitudinal, light stripe from the post-cephalic transverse skinfold to the vent. This species was known only from the PMP and the Urucum Massif, but recently, Silva-Alves et al. (2017) extended its distribution to southwestern Mato Grosso and associated it with seasonally flooded forests. The morphometric variation of the specimen listed as ZUFMS-AMP 923 and wrongly indicated as the holotype by Piva et al. (2017: table 1) was actually obtained from ZUFMS-AMP 924, the actual holotype; data presented for the paratype ZUFMS-AMP 924 was actually obtained from the paratype ZUFMS-AMP 923. We found one specimen buried under rocks during the dry season.

\section{Elachistocleis matogrosso Caramaschi, 2010} Figure 4M

Material examined. BRAZIL • 2 ○, $29.97 \mathrm{~mm}, 25.07$ mm; Mato Grosso do Sul, Corumbá, Parque Municipal de Piraputangas; ca $19^{\circ} 16^{\prime} \mathrm{S}, 057^{\circ} 38^{\prime} \mathrm{W}$; 19 Dec. 2012; Alessandher Piva, Nelson R. de Albuquerque leg.; ZUFMS-AMP-923, ZUFMS-AMP-924.

See also Table 1 for annual seasonality, survey areas where found, and total number of individuals found.

Identification. Small to moderate-sized oval frog (SVL 21.5-33.2 mm). Head small, slightly shorter than wide $(10.39 \mathrm{~mm} \times 10.75 \mathrm{~mm})$. Snout sub-elliptical in dorsal view and protruding in profile. Pupil rounded. Tympanum indistinct. Fingers and toes lack adhesive disks and web. Skin of dorsum slightly rough. In life, dorsum gray with thin, central, light stripe from post-cephalic transverse skinfold to venter. Vocal sac darker than venter. Interocular spot absent. Limit between dorsum and belly poorly defined. Belly yellow, immaculate. Large, irregular, light-yellow spot on anterior surface of thigh and groin; narrow, irregular, light-yellow stripe on posterior surface of thigh; irregular, light-yellow stripe on proximal internal surface of shank. Narrow, light stripe surrounding knee and reaching middle of tarsus.

Remarks. We found only two specimens, and both were buried in the soil. Only one other species of Elachistocleis, E. bicolor, with an immaculate venter is known to occur in Mato Grosso do Sul (Caramaschi 2010).

Phyllomedusidae

\section{Phyllomedusa sauvagii Boulenger, 1882}

Figure 4N

Material examined. BRAZIL • 1 o, $80.26 \mathrm{~mm}$; Mato Grosso do Sul, Corumbá, Parque Municipal de Piraputangas; ca $19^{\circ} 16^{\prime} \mathrm{S}, 057^{\circ} 38^{\prime} \mathrm{W}$; 27 Nov. 2012; Alessandher Piva, Nelson R. de Albuquerque leg.; ZUFMS AMP-5167.

See also Table 1 for annual seasonality, survey areas where found, and total number of individuals found.

Identification. Large-sized tree frog with long limbs (SVL 77-88 mm). Head longer than wide (35.19 $\mathrm{mm} \times$ $27.58 \mathrm{~mm})$. Snout slightly truncate in dorsal view and sloped in profile. Eyes relatively protruding. Pupil horizontal. Tympanum distinct. Skin on dorsum smooth. Two prominent parotid glands posterior to eyes. Skin on venter finely granular. Fingers with reduced adhesive disks. Fingers and toes not webbed, with opposable thumbs. In life, dorsum bright-green, immaculate. White striped marking along bottom of mandible that extends to inguinal region. Interocular spot absent. Belly green, with series of irregular white blotches. Flank, thigh, and shank uniform, not mottled.

Remarks. We found ZUFMS-AMP 5167 perched on a shrub as high as $200 \mathrm{~cm}$ above the ground, on grassy vegetation around one of the permanent ponds.

\section{Pithecopus azureus (Cope, 1862a)}

Figure $4 \mathrm{O}$

Material examined. BRAZIL • 1 ก, 35.08 mm; Mato Grosso do Sul, Corumbá, Parque Municipal de Piraputangas; ca $19^{\circ} 16^{\prime} \mathrm{S}, 057^{\circ} 38^{\prime} \mathrm{W}$; 30 Oct. 2012; Alessandher Piva, Nelson R. de Albuquerque leg.; ZUFMS AMP-5166.

See also Table 1 for annual seasonality, survey areas where found, and total number of individuals found.

Identification. Moderate-sized leaf frog with long limbs (SVL 31.2-44.4 mm). Head longer than wide (11.15 mm $\times 9.64 \mathrm{~mm})$. Snout truncate in dorsal view and sloped in profile. Snout slightly truncate in dorsal view and sloped in profile. Pupil horizontal. Skin on dorsum and venter 
smooth and granular, respectively. Two small parotid glands posterior to eyes. Fingers and toes not webbed. In life, dorsum green, immaculate. Interocular blotch absent. Belly cream, immaculate. Wide, orange bands with transverse, dark bars on posterolateral part of flank, on anterior and posterior surfaces of thigh, on posterior surface of shank, and on anterior surface of shank.

Remarks. We found 30 specimens perched on low vegetation as high as $150 \mathrm{~cm}$ above the ground, on grassy vegetation around one of the permanent ponds, and on soil. This species is most similar to Phyllomedusa sauvagii in its general morphology and coloration, because both have a cream-colored, immaculate venter, relatively protruding eyes, two parotid glands, a distinct tympanum, and reduced adhesive disks on the fingers and toes (both not webbed).

\section{Discussion}

The similarity between the phytophysiognomy and types of substrate of Areas 1 and 3 may have favored the abundance of the most frequently seen species, Dendropsophus minutus. Boana raniceps, the second most abundant species, was observed throughout the sampling period. Together, these species seem to exhibit a certain tolerance to periods of higher ambient temperature in the Pantanal. Leptodactylus podicipinus, however, was probably seen most frequently in Area 2 because the area is predominantly characterized by permanent and ephemeral ponds, which are the types of habitat that this prolonged breeding species uses to nest (Prado et al. 2005). The species of Rhinella were strongly associated with terrestrial substrates. The hylids Dendropsophus melanargyreus, D. nanus, Scinax acuminatus, S. fuscovarius, and Trachycephalus typhonius, and the phyllomedusids, Phyllomedusa sauvagii, and Pithecopus azureus demonstrated a preference for tree-trunks or shrubs.

We recorded 29 species in the PMP, which is the most species we are aware of in the municipality of Corumbá. Although Ávila and Ferreira (2004) documented the presence of Leptodactylus syphax Bokermann, 1969 and Pithecopus hypochondrialis (Daudin, 1800) in Corumbá, we were unable to confirm the presence of these species in the PMP. Our study confirmed the presence of 13 species not included in their study, namely Adenomera diptyx, Boana raniceps, Chiasmocleis albopunctata, Dendropsophus melanargyreus, D. minutus, Elachistocleis corumbaensis, E. matogrosso, Leptodactylus elenae, L. podicipinus, Phyllomedusa sauvagii, Physalaemus biligonigerus, P. nattereri, and Pithecopus azureus. Altogether, we now know of 31 species in Corumbá, if we also include those species documented by Ávila and Ferreira (2004) but not found by us in the PMP.

Souza et al. (2017) noted that the semideciduous forests in the state of Mato Grosso do Sul are home to as many as 57 anuran species, but the precise taxonomic status of some species is uncertain (e.g., Rhinella aff. scitula, Boana aff. geographicus). Additionally, some species [e.g., Boana crepitans (Wied-Neuwied, 1824), Odontophrynus americanus (Duméril \& Bibron, 1841)] recorded by Souza et al. (2017) occur elsewhere (i.e., not on the western border of Pantanal).

Our results are consistent with those of other studies conducted on or near the western border of the Pantanal, which also found a high diversity of anurans. Prado et al. (2005) identified 24 species in the subregions Miranda and Abobral (southern Pantanal), municipality of Corumbá, which are characterized by open formations in the Cerrado domain (savanna-like vegetation), with fields and patches of semideciduous forest. ValérioBrun et al. (2010) found 34 species of anurans in the Pantanal of Poconé, recording more hylid frogs, including seven that were not present among the species observed by us. Pansonato et al. (2011) evaluated the anuran species richness and abundance in the northwestern area of the Pantanal, municipality of Cáceres, and identified 34 species, notably two species of Pseudopaludicola Miranda-Ribeiro, 1926 not identified in our study. Souza et al. (2014) recorded 24 species in an agroecosystem along the south-eastern border of the Pantanal, including an unidentified Pseudopaludicola and Lysapsus limellum Cope, 1862, whereas Gordo and Campos (2005) recorded 33 species in Serra do Jacadigo, Maciço do Urucum, Serra de Maracaju, and Serra da Bodoquena (in the surrounding southern Pantanal). However, we expect that the species richness and distribution of amphibians on the western border of the Pantanal will increase with further explorations and additional sampling efforts, as the PMP was surveyed only three times a month for just one year. Elachistocleis corumbaensis Piva, Caramaschi \& Albuquerque, 2017, for example, was described from specimens collected during this survey. Moreover, a combination of pitfall traps and hand collection would be the most effective approach because pitfall traps are extremely useful for sampling anurans (e.g., Cechin and Martins 2000). Similarly, the low number of species (i.e., nine species) recorded in the Prefeitura Municipal de Corumbá (2008) was probably due to the limited sampling effort.

Of the 29 anurans that occur within the boundaries of PMP, 25 are assessed as Least Concern by the International Union for the Conservation of Nature (IUCN 2020), two species are Data Deficient, and two species are not assessed (Table 1), which indicates the need for more studies before these four species can be properly assessed. According to Aquino et al. (2004), local populations of Physalaemus nattereri, a Least Concern species, are in decline due to the spread of intensive agriculture in the Cerrado biome.

In this study we present the diversity of the anuran fauna of a protected area in Corumbá along the western border of the Pantanal. This region, a priority area for biodiversity conservation, has high biological diversity, and its natural habitats are threatened by anthropogenic activities, such as landscape conversions (i.e., forest to pastures for cattle), introduction of exotic species, and 
mining activities (Alho 2011). In 2020, the number of forest fires in the Pantanal has nearly tripled compared to the previous year, and Corumbá is the most severely affected town in the region (INPE 2020). If wildfires continue, they will devastate an ecosystem that is home to an immense wealth of biodiversity with more than 2,000 plants, and 1,200 vertebrates, and countless invertebrates and microorganisms (Tomas et al. 2019). Our study fills knowledge gaps in the anuran fauna in the western border of Pantanal, and it will serve as a basis for additional studies that are needed to understand how the anurans respond to habitat loss or fragmentation because of the aforementioned impacts.

\section{Acknowledgements}

Fundação de Meio Ambiente do Pantanal permitted research to be conducted at Parque Municipal de Piraputangas. Ledilene Alves and Rafaela Molina provided field assistance. Wellington Santos Fava prepared the map depicted in Figure 1. Christine Strüssmann and Cynthia Prado helped in the identification of Physalaemus specimens. Liliana Piatti determined the sex of some specimens. Gecele Matos Paggi, Cyro de Luna Dias, and two anonymous reviewers provided very useful suggestions on the manuscript. Editage provided an English editing service. This study was financed in part by the Universidade Federal de Mato Grosso do Sul, Ministério da Educação, Brazil. The Coordenação de Aperfeiçoamento de Pessoal de Nível Superior provided a fellowship to Alessandher Piva during his graduate studies at the Universidade Federal de Mato Grosso do Sul.

\section{Authors' Contributions}

NRA designed the study; AP, FMS, ASU, MPS, MVSU and NRA collected data and specimens; AP and NRA identified most of the specimens; AP analyzed the data; MVSU assisted with fieldwork logistics; NRA wrote the manuscript with input from AP.

\section{References}

Ab'Saber AN (1988) O Pantanal mato-grossense e a teoria dos refúgios. Revista Brasileira de Geografia 50 (2): 9-57.

Achaval F, Olmos A (2007) Anfibios y reptiles del Uruguay. Zonalibro, Montevideo, $160 \mathrm{pp}$.

Amaral CRL, Chaves ACS, Borges Júnior VNT, Pereira F, Silva BM, Silva DA, Amorim A, Carvalho EF, Rocha CFD (2019) Amphibians on the hotspot: molecular biology and conservation in the South American Atlantic Rainforest. PLoS ONE 14 (10): 1-17. https:// doi.org/10.1371/journal.pone.0224320

Alho CJR (2011) Biodiversity of the Pantanal: its magnitude, human occupation, environmental threats and challenges for conservation. Brazilian Journal ofBiology 71 (1):229-232.https://doi.org/10. 1590/S1519-69842011000200001

AmphibiaWeb (2009) Trachycephalus typhonius: Pepper Treefrog http://amphibiaweb.org/species/1025. University of California, Berkeley, CA, USA. Accessed on: 2020-11-22.

AquinoL, ReichleS, SilvanoD,ScottN(2004)Physalaemusnattereri. The IUCN Red List of Threatened Species 2004: e.T57267A11597340. https://doi.org/10.2305/iucn.uk.2004.rlts.t57267a11597340.en. Accessed on: 2020-4-17.

Ávila RW, Ferreira VL (2004) Riqueza e densidade de vocalizações de anuros (Amphibia) em uma área de Corumbá, Mato Grosso do Sul, Brasil. Revista Brasileira de Zoologia 21: 887-892.

Beck J, Schwanghart W (2010) Comparing measures of species diversity from incomplete inventories: an update. Methods in Ecology and Evolution 1 (1): 38-44. https://doi.org/10.1111/j.2041-210X. 2009.00003.x

Bernarde PS, Kokubum MCN (1999) Anurofauna do Município de Guararapes, Estado de São Paulo, Brasil (Amphibia: Anura). Acta Biológica Leopoldensia 21 (1): 89-97.

Boff S, Araujo AC, Pott A (2013) Bees (Hymenoptera: Apoidea) and flowers of natural forest patches of southern Pantanal. Biota Neotropica 13 (4): 46-56. https://doi.org/10.1590/S1676-060320130004 00005

Boettger O (1885) Liste von reptilien und batrachiern aus Paraguay. Zeitschrift für Naturwissenschaften 58: 213-248.

Bokermann WCA (1969) Uma nova espécie de Leptodactylus de Mato Grosso (Anura, Leptodactylidae). Revista Brasileira de Biologia 29: $13-16$.

Boulenger GA (1882) Catalogue of the Batrachia Salientia s. Ecaudata in the collection of the British Museum. Second edition. Taylor and Francis, London, UK, 256 pp.

Boulenger GA (1889) On a collection of batrachians made by Prof. Charles Spegazzini at Colonia Resistencia, South Chaco, Argentine Republic. Annali del Museo Civico di Storia Naturale di Genova. Serie 2, 7: 246-249.

Burmeister H (1861) Reise Durch Die La Plata-Staaten Mit Besonderer Rücksicht Auf Die Physische Beschaffenheit Und Den Culturzustand Der Argentinische Republik. Ausgefuhrt in den Jahren 1857, 1858, 1859 unb 1860. Volume 2. H.W. Schmidt, Halle, 503 pp.

Caramaschi U (2010) Notes on the taxonomic status of Elachistocleis ovalis (Schneider, 1799) and description of five new species of Elachistocleis Parker, 1927 (Amphibia, Anura, Microhylidae). Boletim do Museu Nacional, Nova Serie, Zoologia 527: 1-30.

Caramaschi U (2006) Redefinição do grupo de Phyllomedusa hypochondrialis, com redescrição de P. megacephala (Miranda-Ribeiro, 1926), revalidação de $P$. azurea Cope, 1862 e descrição de uma nova espécie (Amphibia, Anura, Hylidae). Arquivos do Museu Nacional, Rio de Janeiro 64 (2): 159-179.

Caramaschi U, Cruz CAG (1997) Redescription of Chiasmocleis albopunctata 1927 (Boettger) and description of a new species of Chiasmocleis (Anura: Microhylidae). Herpetologica 53 (2): 259268.

Cechin SZ, Martins M (2000) Eficiência de armadilhas de queda (pitfall traps) em amostragens de anfíbios e répteis no Brasil. Revista Brasileira de Zoologia 17 (3): 729-740. https://doi.org/10.1590/S01 01-81752000000300017_

Cei JM (1980) Amphibians of Argentina. Monitore Zoologico Italiano. Nuova Serie, Monographia 2. Università degli Studi di Firenze, Firenze, Italy, ixii + 609 pp.

Cope ED (1861 “1860”) Descriptions of new species of the reptilian genera Hyperolius, Liuperus and Tropidodipsas. Proceedings of the Academy of Natural Sciences of Philadelphia 12: 517-518.

Cope ED (1862a) Catalogues of the reptiles obtained during the explorations of the Parana, Paraguay, Vermejo and Uraguay Rivers, by Capt. Thos. J. Page, U.S.N.; and of those procured by Lieut. N. Michler, U.S. Top. Eng., Commander of the expedition conducting the survey of the Atrato River. Proceedings of the Academy of Natural Sciences of Philadelphia 14: 346-359.

Cope ED (1862b) On some new and little known American Anura. Proceedings of the Academy of Natural Sciences of Philadelphia 14: $151-159$.

Cope ED (1887) Synopsis of the Batrachia and Reptilia obtained by H. H. Smith, in the Province of Mato Grosso, Brazil. Proceedings of the American Philosophical Society 24: 44-60.

Crump ML, Scott-Jr NJ (1994) Visual encounter surveys. In: Heyer 
WR, Donnelly MA, McDiarmid RW, Hayek LAC, Foster MS (Eds) Measuring and monitoring biological diversity. Standard methods for amphibians. Smithsonian Institution Press, Washington, 84-92.

Damasceno-Junior GA, Pott A, Pott VJ, Da Silva JSV (2009) Florestas estacionais do Pantanal. Considerações florísticas e subsídios para a conservação. Geografia (Rio Claro) 34 (Número Especial): 697-707.

Daudin F-M(1800) Histoire naturelle des quadrupèdes ovipares. Livraison 2. Marchant et Cie, Paris, France, 24 unnumbered pp. https://doi .org/10.5962/bhl.title.5020

De-Carvalho CB, Freitas EB, Faria RG, Batista RC, Batista CC, Coelho WA, Bocchiglieri A (2008) Natural history of Leptodactylus mystacinus and Leptodactylus fuscus (Anura: Leptodactylidae) in the Cerrado of Central Brazil. Biota Neotropica 8 (3): 105115. https://doi.org/10.1590/S1676-06032008000300010

de Sá Rafael O, Grant T, Camargo A, Heyer WR, Ponssa ML, Stanley E (2014) Systematics of the Neotropical genus Leptodactylus Fitzinger, 1826 (Anura: Leptodactylidae): Phylogeny, the relevance of non-molecular evidence, and species accounts. South American Journal of Herpetology 9 (Special Issue 1): S1-S100. https://doi org/10.2994/sajh-d-13-00022.1

Duellman, WE (1970) The hylid frogs of Middle America. Vol. 1. Monograph of the Museum of Natural History, University of Kansas 1: $1-427$.

Duméril AMC, Bibron G (1841) Erpétologie genérale ou histoire naturelle complète des reptiles. Volume 8. Librarie Enclyclopedique de Roret, Paris, France, 792 pp. https://doi.org/10.5962/bhl. title. 45973

Forti LR, Tissiani ASO, Mott T, Strüssmann C (2011). Diet of Ameerega braccata (Steindachner, 1864) (Anura: Dendrobatidae) from Chapada dos Guimarães and Cuiabá, Mato Grosso State, Brazil. Brazilian Journal of Biology 71 (1): 189-196. https://doi. org/10.1590/S1519-69842011000100027

Frost DR (2020) Amphibian species of the world: an online reference. Version 6.0.http://research.amnh.org/herpetology/amphibia/index. html. American Museum of Natural History, New York, USA https://doi.org/10.5531/db.vz.0001. Accessed on: 2020-11-22.

Gallardo JM (1961) On the species of Pseudidae (Amphibia, Anura). Bulletin of the Museum of Comparative Zoology at Harvard College 125: 109-134.

Garda, AA, Santana DJ, São-Pedro VA (2010) Taxonomic characterization of paradoxical frogs (Anura, Hylidae, Pseudae): geographic distribution, external morphology, and morphometry. Zootaxa 2666: 1-28. https://doi.org/10.11646/zootaxa.2666.1.1

Gehara M, Crawford AJ, Orrico VGD, Rodríguez A, Lötters S, et al (2014) High levels of diversity uncovered in a widespread nominal taxon: continental phylogeography of the Neotropical tree frog Dendropsophus minutus. PLoS ONE 9 (9): e103958. https://doi.org/ 10.1371/journal.pone.0103958

Gordo M, Campos ZMS (2005) Anuros das serras de entorno do Pantanal sul. Embrapa Pantanal, Série Documentos 78, 1-20.

Heyer WR (1978) Systematics of the fuscus group of the frog genus Leptodactylus (Amphibia, Leptodactylidae). Science Bulletin 29: $1-85$.

Heyer MM, Heyer WR, Spear S, de Sa RO (2003) Leptodactylus mystacinus. Catalogue of American amphibians and reptiles. Society for the Study of Amphibians and Reptiles 767.1-767.11.

INPE (Instituto Nacional de Pesquisas Espaciais) (2020) Banco de Dados de Queimadas. http://www.inpe.br/queimadas/bdqueimadas. Accessed on: 2020-11-22

IUCN (International Union for the Conservation of Nature) (2020) The IUCN Red List of threatened species. Version 2020-1. https:// www.iucnredlist.org. Accessed on: 2020-4-16.

Kwet A, Lingnau R, Di Bernardo M (2010) Pró-Mata: Anfíbios da serra gaúcha, sul do Brasil - Amphibien der Serra Gaúcha, Südbrasilien - Amphibians of the serra gaúcha, south of Brazil. 2nd Edition, revised and enlarged. Brasilien-Zentrum de Universität
Tübingen, Tübingen, Germany, and EDIPUCRS, Porto Alegre, Brazil, 148 pp.

Lehn CR, Alves FM, Damasceno-Junior GA (2008) Florística e fitossociologia de uma área de cerrado sensu stricto na região da borda oeste do Pantanal, Corumbá, MS, Brasil. Pesquisas, Botânica 59: $129-142$.

Linnaeus C (1758) Systema naturae per regna tria naturae, secundum classes, ordines, genera, species, cum characteribus, differentiis, synonymis, locis ... Edicio decima, reformata. Tomus I. Laurentii Salvii, Stockholm, Sweden, 824 pp. https://doi.org/10.5962/bhl. title. 542

Lutz A (1925) Batraciens du Brésil. Comptes Rendus et Mémoires Hebdomadaires des Séances de la Société de Biologie et des ses Filiales 2: 211-214.

McDiarmid RW (1994) Preparing amphibians as scientific specimens In: Heyer WR, Donnelly MA, McDiarmid RW, Hayek LAC, Foster MS (Eds) Measuring and monitoring biological diversity. Standard methods for amphibians. Smithsonian Institution Press, Washington, DC, USA, 289-297.

Miles L, Newton AC, Defries RS, Ravilious C, May I, Blyth S, Kapos V, Gordon JE (2006) A global overview of the conservation status of tropical dry forests. Journal of Biogeography 33 (3): 491-505.

Miranda-Ribeiro A (1926) Notas para servirem ao estudo dos gymnobatrachios (Anura) brasileiros. Pimenta de Mello, Rio de Janeiro, Brazil, 227 pp.

Müller L, Hellmich W (1936) Amphibien und Reptilien. I. Teil: Amphibia, Chelonia, Loricata. In: Krieg H (Ed.) Wissenschaftliche Ergebnisse der Deutschen Gran Chaco-Expedition. Vol. [4]. Strecker und Schröder, Stuttgart, Germany, 1-120.

Narvaes P, Rodrigues MT (2009) Taxonomic revision of Rhinella granulosa species group (Amphibia, Anura, Bufonidae), with a description of a new species. Arquivos de Zoologia 40: 1-73.

Norman DR (1994) Anfibios y reptiles del Chaco Paraguayo, Tomo 1. Amphibians and Reptiles of the Paraguayan Chaco, Volume 1. Privately printed by the author, San José, Costa Rica, 281 pp.

Pansonato A, Mott T, Strüssmann, C (2011) Anuran amphibians' diversity in a northwestern area of the Brazilian Pantanal. Biota Neotropica 11 (4): 77-86. https://doi.org/10.1590/S1676-06032011 000400008

Peel MC, Finlayson BL, McMahon TA (2007) Updated world map of the Köppen-Geiger climate classification. Hydrology and Earth System Sciences 11: 1633-1644. https://doi.org/10.5194/hess-111633-2007

Penha J, Strüssmann C, Girad P (2010) Repensando a experiência do grupo do Pantanal Norte com o sistema de grades. In: Fernandes IM, Signor C, Penha J (Eds) Biodiversidade no Pantanal de Poconé. Centro de Pesquisa do Pantanal, Cuiabá, 183-190.

Peters WCH (1872) Über eine Sammlung von Batrachiern aus Neu Freiburg in Brasilien. Monatsberichte der Königlichen Preussische Akademie des Wissenschaften zu Berlin 1872: 680-684.

Piva A (2014) Diversidade de anfíbios anuros (Anura) em uma área de floresta estacional semidecidual no Parque Municipal de Piraputangas, em Corumbá, MS. Master's thesis, Universidade Federal de Mato Grosso do Sul, Campo Grande, 19 pp.

Piva A, Caramaschi U, Albuquerque NR (2017) A new species of Elachistocleis (Anura: Microhylidae) from the Brazilian pantanal. Phyllomedusa 16 (2): 143-154. https://doi.org/10.11606/issn.23169079.v16i2p143-154

Pott A, Silva JSV, Salis SM, Pott VJ, Silva MP (2000) Vegetação e uso da terra. In: Silva JSV (Ed.) Zoneamento ambiental da borda oeste do Pantanal: maciço do Urucum e adjacências. Embrapa Comunicação para Transferência de Tecnologia, Brasília, Brazil, 111-131.

Prado CPA, Uetanabaro M (2000) Reproductive biology of Lysapsus limellus Cope, 1862 (Anura, Pseudidae) in the Pantanal, Brazil. Zoocriaderos 3 (1): 25-30.

Prado CPA, Uetanabaro M, Haddad CFB (2005) Breeding activity patterns, reproductive modes, and habitat use by anurans (Amphibia) in a seasonal environment in the Pantanal, Brazil. Amphibia-Rep- 
tilia 26 (2): 211-221. https://doi.org/10.1163/1568538054253375

Prefeitura Municipal de Corumbá (2008) Plano de manejo para o Parque Municipal de Piraputangas, Corumbá, Brazil, 236 pp.

Roque FO, Ochoa-Quintero J, Ribeiro DB, Sugai LS, Costa-Pereira R, Bino G (2016) Upland habitat loss as a threat to Pantanal wetlands. Conservation Biology 30 (5): 1131-1134. https://doi.org/10.1111/co bi.12713

Savage JM (2002) The amphibians and reptiles of Costa Rica: a herpetofauna between two continents, between two seas. University of Chicago Press, Chicago, Illinois, USA, 934 pp.

Segalla MV, Caramaschi U, Cruz CAG, Garcia PCA, Grant T, Haddad CFB, Santana DJ, Toledo LF, Langone JA (2019) Brazilian amphibians: list of species. Herpetologia Brasileira 3 (1): 65-96.

Schneider JG (1799) Historiae amphibiorum naturalis et literariae. Fasciculus primus continens ranas, calamitas, bufones, salamandras et hydros in genera et species descriptos notisque suis distinctos. Friederici Frommanni, Jena, 264 pp. https://doi.org/10.5962/ bhl.title. 4270

Silva JSV, Abdon MMA (1998) Delimitação do Pantanal brasileiro e suas sub-regiões. Pesquisa Agropecuária Brasileira 33 (No. Especial): 1703-1711.

Silva-Alves VD, D’Ávila RS, Costa TM, Barbosa APD, Brum BR, Silva CPA, Ignácio ARA, Carniello MA, Muniz CC, Santos Filho M, Seba MFR, Nogueira OMA, Silva JSH, Gusmão AC, Mudrek JR, Silva OD, Canale GR (2019) Geographic range extension of Elachistocleis corumbaensis Piva, Caramaschi \& Albuquerque, 2017 (Anura, Microhylidae) with new records in ecotonal zones in the state of Mato Grosso, Brazil. Check List 15 (1): 17-20. https:// doi.org/10.15560/15.1.17

Silvano DL, Segalla MV (2005) Conservation of Brazilian amphibians. Conservation Biology 19 (3): 653-658. https://doi.org/10.1111/ j.1523-1739.2005.00681.x

Souza FL, Martins FI, Raizer J (2014) Habitat heterogeneity and anuran community of an agroecosystem in the Pantanal of Brazil. Phyllomedusa 13 (1): 41-50. http://doi.org/10.11606/issn.2316-9079.v13i1 p41-50

Souza FL, Prado CPA, Sugai JLMM, Ferreira VL, Aoki C, Landgref-Filho P, Strüssmann C, Ávila RW, Rodrigues DJ, Albuquerque NR, Terra J, Uetanabaro M, Béda AF, Piatti L, Kawashita-Ribeiro RA, Delatorre M, Faggioni GP, Demczuk SDB, Duleba S (2017) Diversidade de anfíbios do Estado de Mato Grosso do Sul, Brasil. Iheringia, Série Zoologia 107: e2017152. http://doi.org/ 10.1590/1678-4766e2017152

Spix JB von (1824) Animalia nova sive species novae testudinum et ranarum quas in itinere per brasiliam annis MDCCCXVIIMDCCCXX jussu et auspiciis Maximiliani Josephi I. Bavariae Regis. F. S. Hübschmann, Munich, Germany, 53 pp.

Steindachner F (1863) Über einige neue Batrachier aus den Sammlungen des Wiener Museums. Sitzungsberichte der Kaiserlichen Akademie der Wissenschaften, Mathematisch-Naturwissenschaftliche Classe 48: 186-192.

Steindachner F (1864) Batrachologische Mittheilungen. Verhandlungen der Kaiserlich-Königlichen Zoologisch-Botanischen Gesellschaft in Wien 14: 239-288.

Strüssmann C, Ribeiro RAK, Ferreira VL, Beda AF (2007) Herpeto- fauna do pantanal brasileiro. In: Nascimento L, Oliveira ME (Eds) Herpetologia no Brasil II. Sociedade Brasileira de Herpetologia Belo Horizonte, Brazil, 66-84.

Strüssmann C, Prado CPA, Ferreira VL, Kawashita-Ribeiro R (2011) Diversity, ecology, management and conservation of amphibians and reptiles of the Brazilian Pantanal: a review. In: Junk WJ, Da Silva CJ, Nunes da Cunha C, Wantzen KM (Eds) The Pantanal: ecology, biodiversity and sustainable management of a large Neotropical seasonal wetland. Pensoft Publishers, Sofia, Bulgaria, 495-519.

Takahasi A, Meirelles ST (2014) Ecologia da vegetação herbácea de bancadas lateríticas (cangas) em Corumbá, MS, Brasil. Hoehnea 41 (4): 515-528. https://doi.org/10.1590/2236-8906-63/2013

Tomas WM, Roque FO, Morato RG, Medici PE, Chiaravalloti RM, Tortato FR, Penha JMF, Izzo TJ, Garcia LC, Lourival RFF, Girard $\mathrm{P}$, Albuquerque NR, Almeida-Gomes M, Andrade MHS, Araujo FAS, Araujo AC, Arruda EC, Assunção VA, Battirola LD, Benites M, Bolzan FP, Boock JC, Bortolotto IM, Brasil MS, Camilo AR, Campos Z, Carniello MA, Catella AC, Cheida CC, Crawshaw PG, Crispim SMA, Damasceno Junior GA, Desbiez ALJ, Dias FA, Eaton DP, Faggioni GP, Farinaccio MA, Fernandes JFA, Ferreira VL, Fischer EA, Fragoso CE, Freitas GO, Galvani F, Garcia AS, Garcia CM, Graciolli G, Guariento RD, Guedes NMR, Guerra A, Herrera HM, Hoogesteijn R, Ikeda SC, Juliano RS, Kantek DLZK, Keuroghlian A, Lacerda ACR, Lacerda ALR, Landeiro VL, Laps RR, Layme V, Leimgruber P, Rocha FL, Mamede S, Marques DKS, Marques MI, Mateus LAF, Moraes RN, Moreira TA, Mourão GM, Nicola RD, Nogueira DG, Nunes AP, Cunha CN, Oliveira MD, Oliveira MR, Paggi GM, Pellegrin AO, Pereira GMF, Peres IAHFS, Pinho JB, Pinto JOP, Pott A, Provete DB, Reis VDA, Reis LK, Renaud P-C, Ribeiro DB, Rossetto OC, Sabino J, Rumiz D, Salis SM, Santana DJ, Santos SA, Sartori AL, Sato M, Schuchmann K-L, Scremin-Dias E, Seixas GHF, Severo-Neto F, Sigrist MR, Silva A, Silva CJ, Siqueira Al, Soriano BMA, Sousa LM, Souza FL, Strüssmann C, Sugai LSM, Tocantins N, Urbanetz C, Valente-Neto F, Viana DP, Yanosky A, Junk WJ (2019) Sustainability agenda for the Pantanal wetland: perspectives on a collaborative interface for science, policy, and decision-making. Tropical Conservation Science 12: 1-30. https://doi. org $/ 10.1177 / 1940082919872634$

Tschudi JJ von (1838) Classification der Batrachier mit Berücksichtigung der Fossilen Thiere dieser Abtheilung der Reptilien. Petitpierre, Neuchatel, Switzerland, 99 pp.

Uetanabaro M, Prado CPA, Rodrigues DJ, Gordo M, Campos Z (2008) Guia de campo dos anuros do Pantanal e planaltos de entorno. Field guide to the anurans of Pantanal and surrounding cerrados. Editora da UFMS, Editora da UFMT, Campo Grande e Cuiabá, Brazil, 196 pp.

Valério-Brun LM, Pansonato A, Solino-Carvalho LA, Strüssmann C, Mott T, Silveira, RML (2010) Sapos, rãs e pererecas. In: Fernandes IM, Signor CA, Penha J (Eds) Biodiversidade no Pantanal de Poconé. Áttema, Manaus, Brazil, 119-136.

Wied-Neuwied MAP Prinz zu (1824) Abbildungen zur Naturgeschichte Brasiliens. Heft 8. Landes-Industrie-Comptoir, Weimar, Germany, 614 pp. 